\title{
Geology of the
}

\section{Rattlesnake Quadrangle}

\section{Bearpaw Mountains}

\section{Blaine County, Montana}

By B. C. HEARN, JR., W. T. PECORA, and W C SWADLEY

CONTRIBUTIONS TO GENERAL GEOLOGY

GEOLOGICALSURVEY B ULLETIN 1181-B

$A$ description of the rocks, structure, and economic resources of part of the central arch and southern volcanic field of the Bearpaw Mountains and surrounding plains

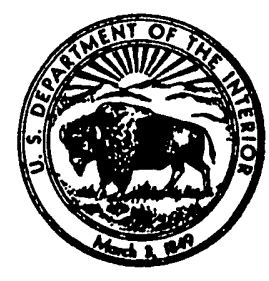




\title{
UNITED STATES DEPARTMENT OF THE INTERIOR
}

\author{
STEWART L. UDALL, Secretary
}

\section{GEOLOGICAL SURVEY}

Thomas B. Nolan, Director

The U.S. Geological Survey Library catalog card for this publication appears on page after index. 


\section{CONTENTS}

\begin{tabular}{|c|c|}
\hline & Page \\
\hline & B1 \\
\hline nd acknowledgments & 2 \\
\hline eography & 3 \\
\hline Geologic history & 4 \\
\hline Sedimentary rocks, & 5 \\
\hline Mississippian System & 6 \\
\hline Mission Canyon Limestone & 6 \\
\hline Jurassic System & 7 \\
\hline Sawtooth Formation & 7 \\
\hline Rierdon Formation & 10 \\
\hline Swift Formation & 10 \\
\hline Cretaceous System & 11 \\
\hline Kootenai Formation & 11 \\
\hline Colorado Shale. & 12 \\
\hline Fall River Sandstone Member & 12 \\
\hline Skull Creek Shale and Newcastle Sandstone Members...... & 13 \\
\hline Mowry Shale Member & 14 \\
\hline Belle Fourche Shale Member. & 14 \\
\hline Greenhorn Limestone Member & 14 \\
\hline Carlile Shale and Niobrara Shale Members & 15 \\
\hline Telegraph Creek Member & 15 \\
\hline Montana Group & 16 \\
\hline Eagle Sandstone & 16 \\
\hline Claggett Shale $\ldots \ldots \ldots$ & 17 \\
\hline (-n & 17 \\
\hline aw Shale & 19 \\
\hline Sandstone. & 20 \\
\hline Hell Creek Formation & 21 \\
\hline ( & 24 \\
\hline Fort Union Formation & 24 \\
\hline Wasatch Formation & 26 \\
\hline (1, & 27 \\
\hline tem & 28 \\
\hline - n- & 28 \\
\hline Quaternary(?) System & 28 \\
\hline Myrtle Butte rockslide & 28 \\
\hline 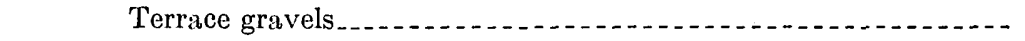 & 29 \\
\hline Quaternary System ........ & 30 \\
\hline Glaciofluvial deposits _. - & 30 \\
\hline 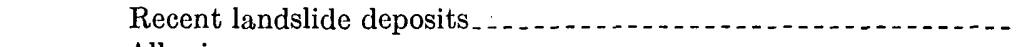 & 31. \\
\hline - & 31 \\
\hline
\end{tabular}


Igneous rocks

Intrusive rocks $\ldots \ldots$

Shonkinite....... 35

Syenite and mafic syenite....

Porphyritic latite.... 36

Porphyritic syenite $\ldots \ldots \ldots \ldots \ldots$

Metamorphism

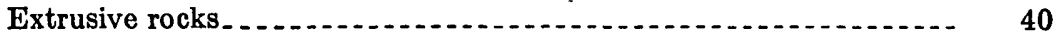

Mafic flow rocks._.

Mafic pyroclastic rocks._.

Felsic flow rocks._.

Felsic pyroclastic rocks...

Structure._._.

Regional setting

Bearpaw Mountains structural arch...

Structural relief and pattern

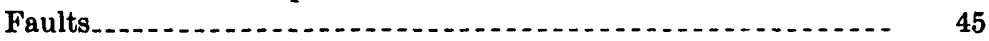

Folds_._.

Effect of intrusions.

Form and structure of intrusions

Hansen Creek dome.

Taylor Butte dome.

Timber Butte intrusion.......... 50

Depth of deformation. 51

Southern volcanic field.

Significance of faulted volcanic rocks

Faults bordering the volcanic field.

Central faulted area

Collapse blocks near Rattlesnake Butte............. 55

The plains area. 57

Fault-fold lineaments._.

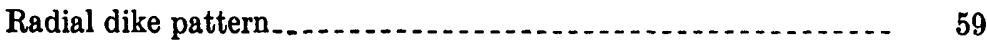

Slide hypothesis of Reeves.

Economic geology . . .

References cited.

Index

\section{ILLUSTRATIONS}

Plate 1. Geologic map and sections of the Rattlesnake quadrangle. In pocket Froure 1. Index map of north-central Montana showing location of Rat-

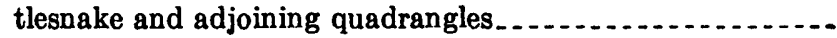

\section{TABLE}

TABLE 1. Chemical analyses, norms, and modes of igneous rocks from the Rattlesnake quadrangle. 


\title{
CONTRIBUTIONS TO GENERAL GEOLOGY
}

\section{GEOLOGY OF THE RATTLESNAKE QUADRANGLE BEARPAW MOUNTAINS, BLAINE COUNTY MONTANA}

\author{
By B. C. Hearn, Jr., W. T. Pecora, and W C Swadley
}

\section{ABSTRACT}

The Rattlesnake quadrangle covers about 200 square miles in the semiarid and sparsely populated southeastern part of the Bearpaw. Mountains and adjacent plains. Exposed sedimentary rocks range in age from Mississippian (Mission Canyon Limestone) to early Eocene (Wasatch Formation). Surficial deposits of Tertiary to Recent age include pediment and terrace gravels deposited on as many as six separate levels of erosion, rock slide and landslide deposits, alluvium, and glaciofluvial sediments deposited along a melt-water channel and in the vicinity of a temporary glacial lake.

Igneous activity in the middle to late Eocene produced intrusive shonkinite and related syenite, porphyritic latite, and porphyritic syenite, and extrusive sequences comprising flows and pyroclastic deposits of mafic phonolite and porphyritic latite equivalent in composition to shonkinite and intrusive porphyritic latite, respectively. Intrusive rocks occur as sills, dikes, laccoliths, bysmaliths, plugs, and stocks.

The northern half of the area covers parts of the eastern end of the east-trending anticlinal uplift known as the Bearpaw Mountains structural arch. Within the broad composite dome-herein referred to as the Cleveland composite dome-which forms the eastern end of the anticlinal uplift, fold axes, dike patterns, and other structural elements are radial to a central composite stock. The Cleveland composite dome contains many subsidiary domes having igneous cores and trapdoor faults which indicate that forcible intrusion was the cause of doming. Some intrusions having upfaulted roofs but lacking major dilation of the wallrocks are likely to be floored.

An east-trending complexly faulted zone on the south flank of the arch has structural patterns similar to those at the borders of the main volcanic fields which lie north and south of the arch west of this quadrangle. The zone contains both large blocks that were downfaulted before volcanism and downfaulted, tilted remnants of the southern volcanic field. The zone may represent the type of structure beneath the main volcanic fields. Small parts of the eastern edge of the southern volcanic field lie along the western border of the quadrangle, partly in downfaulted contact with older formations. 
The plains area includes three lineaments : two trend northeastward, and one trends northwestward. The lineaments-narrow, elongate zones of deformation-interrupt the nearly horizontal Cretaceous sedimentary rocks and are typical of the belt of folds and faults surrounding the Bearpaw Mountains area. Although they are largely zones of uplift due to anticlinal folding and horst faulting along steep normal and reverse faults, they also include some downfaulted structures and low-angle reverse faults.

The crystalline basement was also uplifted and fractured during the time the radial pattern of structures was forming. Transfer of magma from deep levels to shallow and surficial levels is probably a cause of downfaulting.

Economic resources include water, lignite and subbituminous coal, possible oil and gas, bentonite, bentonitic shale, sand, gravel, road metal, and rip-rap for construction purposes.

\section{INTRODUCTION AND ACKNOWLEDGMENTS}

The Rattlesnake quadrangle is the southeastern of eight 15-minute quadrangles (fig. 1) that encompass the Bearpaw Mountains uplift in north-central Montana. The geologic map (pl. 1) is the eighth of the group recently published by the U.S. Geological Survey. The four western quadrangles (Laredo, Centennial Mountain, Shambo, and

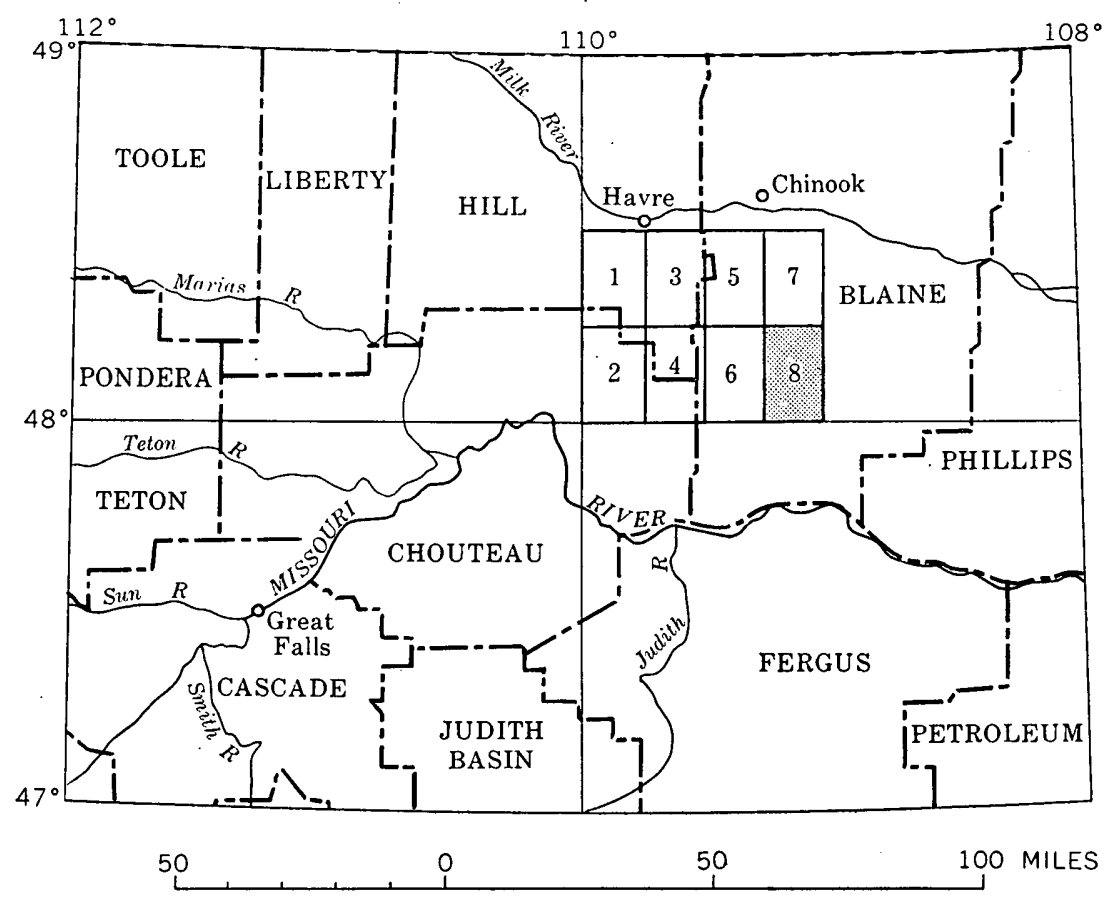

Figure 1.-Index map of north-central Montana showing location of Rattlesnake and adjoining quadrangles. 1, Laredo quadrangle, I-234; 2, Centennial Mountain quadrangle, I-235; 3, Shambo quadrangle, I-236; 4, Warrick quadrangle, I-237 ; 5, Lloyd quadrangle, Bulletin 1081-E; 6, Maddux quadrangle; Bulletin 1081-C; 7, Cleveland quadrangle, Bulletin 1141-P;8, Rattlesnake quadrangle (shaded), this report. 
Warrick) were issued on a planimetric base and were published at a scale of $1: 31,680$ in the Miscellaneous Geological Investigations Series as maps I-234 (Pecora, Witkind, and Stewart), I-235 (Stewart, Pecora, Engstrom, and Dixon), I-236 (Kerr, Pecora, Stewart, and Dixon), and I-237 (Pecora and others). Geological maps of the four eastern quadrangles were issued as Bulletin reports and are identified as Lloyd (Bull. 1081-E, by Schmidt, Pecora, Bryant, and Ernst), Maddux (Bull. 1081-C, by Bryant, Schmidt, and Pecora), Cleveland (Bull. 1141-P, by Schmidt, Pecora, and Hearn), and Rattlesnake (this report).

The Rattlesnake quadrangle was mapped during the summer seasons of 1956, 1957, and 1959 under the field-party leadership of B. C. Hearn, Jr., and the general supervision of W. T. Pecora. W C Swadley participated in 1959. Assistance was given in the field by $R$. D. Bentley and W. G. Ernst in 1956, R. A. Sheppard in 1957, and C. J. Bowser and N. K. Hagen in 1959. The geology was recorded on preliminary topographic field sheets at a scale of $1: 15,840$.

Many courtesies were extended to members of the field party by residents of the area. We are particularly indebted to members of the Boards of Blaine County School Districts 14 and 67 for permission to use the Peoples Creek, Cleveland, and Rattlesnake Schools as field offices and to the U.S. Post Office Department for office space in Havre, Mont., during the project seasons.

In addition to earlier published maps and reports of the region, the authors had access to unpublished reconnaissance maps prepared in 1924 by Frank Reeves and W. S. Burbank of the U.S. Geological Survey, and to doctoral dissertations by W. T. Pecora in $1940^{1}$ and by Bernard Fisher in $1946 .^{2}$ B. C. Hearn, Jr. (1959), prepared a geologic report of the northern half of the Rattlesnake quadrangle.

\section{GEOGRAPHY}

The Rattlesnake quadrangle covers about 200 square miles on the southeastern flank of the Bearpaw Mountains. About 35 people live in the quadrangle; they are engaged chiefly in cattle and sheep ranching and dryland grain farming. The climate is semiarid, the annual precipitation ranging from 10 to 15 inches. Chinook, which is about 30 miles north of the quadrangle, is the closest town; it is on U.S. Route 2 and the Great Northern Railway.

\footnotetext{
${ }^{1}$ Pecora, W. T., 1940, Petrology and mineralogy of the western Bearpaw Mountalns, Montana : Doctoral dissertation, Harvard Univ., 280 p.

a Fisher, Bernard, 1946, Igneous rocks of the northeastern Bearpaw Mountalns, Montana: Doctoral dissertation, Harvard Univ., 127 p.
} 
The present topography formed during the late part of the Cenozoic Era by erosion of rocks of differing resistance. The northern half of the quadrangle contains rounded mountains and buttes of the eastern end of the Bearpaw Mountains; the maximum elevation is 5,566 feet at the summit of Black Butte. A main drainage divide between the Peoples Creek drainage, which is tributary to the Milk River on the north, and the Cow Creek-Suction Creek drainage, which is tributary to the Missouri River on the south, winds through the mountainous area. The southern half of the quadrangle is in the plains area that surrounds the Bearpaw Mountains, and this part of the quadrangle is mainly a dissected benchland which grades into badlands along major drainages. The mimimum elevation in the quadrangle is about 2,840 feet, near the intersection of Cow Creek and Suction Creek.

Vegetation in the northern half of the quadrangle is mainly grass, but in scattered areas a dense cover of conifers grows near talus slopes of large intrusions, particularly on northern slopes. In the southern half of the quadrangle, vegetation comprises grass on benches and areas of low relief, sagebrush and scattered pines on dissected areas of Bearpaw Shale, brush along some valleys, and isolated groves of cottonwood trees along lower Cow Creek.

\section{GEOLOGIC HISTORY}

Regional sedimentation in north-central Montana in the Paleozoic and Mesozoic Eras was principally marine, but in Cenozoic time it was entirely nonmarine. Broad regional uplifts in Jurassic time interrupted continuous marine deposition. During Cretaceous time the sea transgressed and regressed across the area and deposited sediments, and by latest Cretaceous time the sea permanently receded from this part of the Great Plains region. Regional sedimentation ceased in early Eocene time after the deposition of the Wasatch Formation, which contains channel boulders derived from the Rocky Mountain region to the west and southwest.

The long interval of sedimentation was followed by uplift and erosion and then by eruption of magma in middle and late Eocene time. The first major structural feature to form was the Bearpaw Mountains structural arch, and its uplift was accompanied by magmatic activity. The arch and its bordering areas were intruded by dikes, sills, laccoliths, bysmaliths, plugs, and stocks. Volcanic eruptions covered the arch and the bordering plains area with lava flows and pyroclastic rocks. Complex doming and folding of the 
arch occurred during this time of magmatic activity, and apparently the arch was an active structural element throughout middle Eocene time. Block faulting began some time before volcanism and continued into late Eocene time, after volcanism had ceased. Erosion during the rest of the Tertiary period and during the early part of the Quaternary period produced the present topographic configuration and established a drainage pattern that was adjusted to the late Tertiary-early Quaternary Missouri River system. Several erosion surfaces were formed around the Bearpaw Mountains at that time.

A continental ice sheet (Wisconsin age) advanced southeastward across this part of Montana and abutted against the high terrain of the northern, western, and eastern slopes of the Bearpaw Mountains. Most of the Rattlesnake quadrangle lies in the driftless area. Wasting of the ice sheet caused temporary glacial lakes and melt-water channels.

\section{SEDIMENTARY ROCKS}

The total thickness of sedimentary rocks in north-central Montana is about 10,800 feet. In the Bearpaw Mountains area the exposed bedrock stratigraphic units range from early Mississippian to early Eocene in age and total 7,500 feet in thickness. Surficial deposits have a maximum aggregate thickness of about 200 feet. About 3,300 feet of unexposed sedimentary rocks of Paleozoic age has been penetrated by drill holes. A drill hole in sec. 3, T. 28 N., R. $23 \mathrm{E}$. (about 12 miles east of Rattlesnake quadrangle) shows the depth to basement rock beneath the plains surrounding the Bearpaw Mountains. The hole started in the Judith River Formation and reached the crystalline basement at a depth of 7,100 feet.

The rocks exposed in north-central Montana were described by Bowen (1914a, b), Brown and Pecora (1949), Cobban (1945, 1951), Collier and Cathcart (1922), Hunt (1956), Imlay (1952), Imlay and others (1948), Knechtel (1944, 1959), Lindvall (1953; 1956a, b), Pepperberg (1909, 1912), Pierce and Hunt (1937), Stebinger (1914; 1916), and Reeves (1924a, 1929). In addition, the following publications based on recent studies of the Bearpaw Mountains by the U.S. Geological Survey contain descriptions of the mapped units: Bryant, Schmidt, and Pecora (1960); Kerr and others (1957); Pecora, Witkind, and Stewart (1957); Pecora and others (1957); Schmidt and others (1961); Stewart and others (1957); and Schmidt, Pecora, and Hearn (1964). 
The sedimentary units mapped in the Rattlesnake quadrangle are given below:

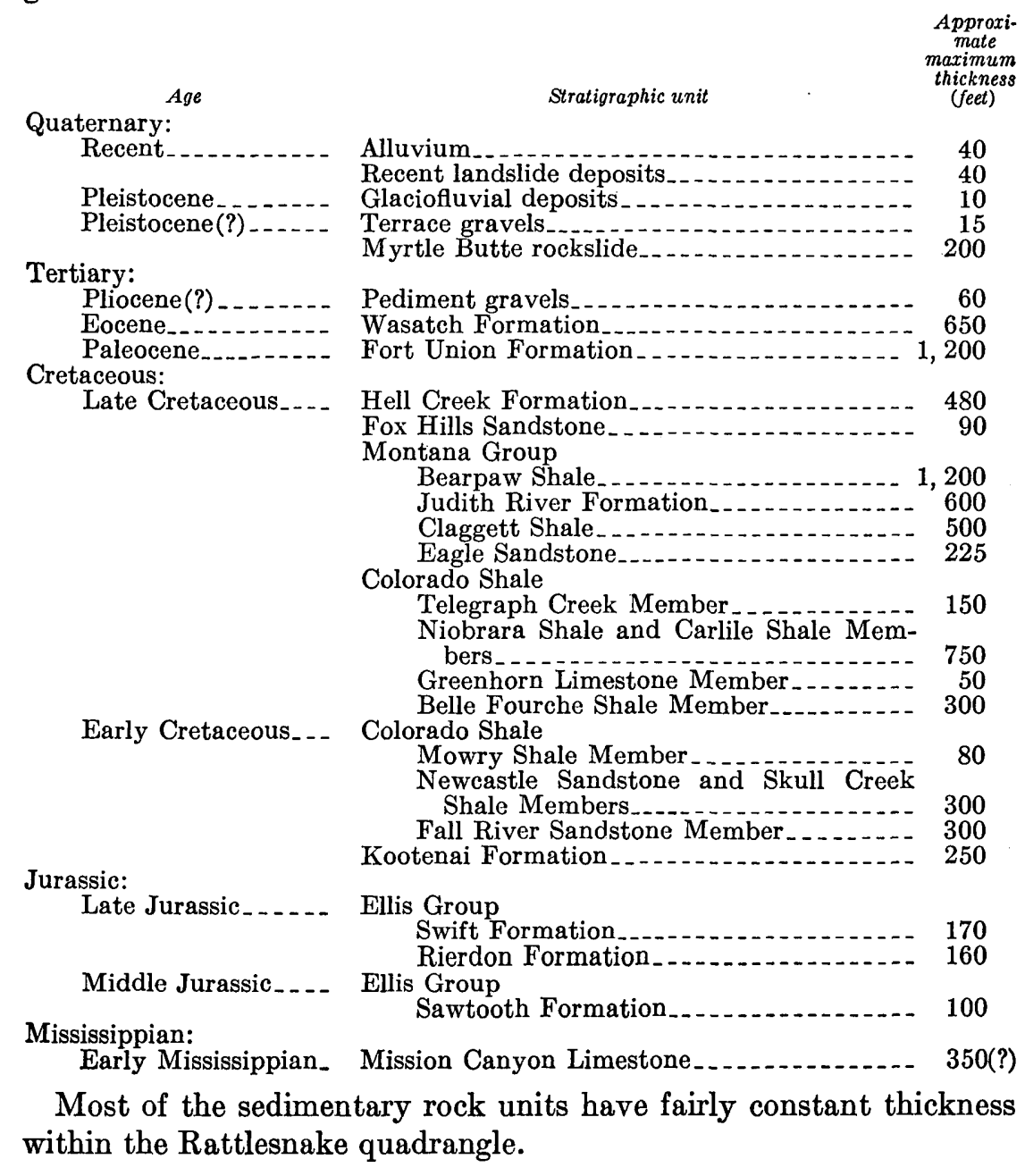

\section{MISSISSIPPIAN SYSTEM}

MISSION CANYON LIMESTONE

In the Rattlesnake quadrangle the oldest rocks exposed-the upper 60 feet of the Mission Canyon Limestone of the Madison Group-are in the Suction Creek dome, secs. 1, 11, and 12, T. 28 N., R. 20 E. These beds are alternate impure and pure massive limestones that weather light and dark gray, respectively. Crinoidal and coralline fossils are abundant, and nodules and lenses of chert occur in the impure limestone beds. The underlying Lodgepole Limestone of the Madison Group is not exposed in the Bearpaw Mountains but is 
shown in sections $A-A^{\prime}, B-B^{\prime}$, and $C-C^{\prime}$ (pl. 1) below an estimated thickness of 350 feet of Mission Canyon Limestone. The total thickness of the Madison Group in the Bearpaw Mountains area, as determined by drilling, ranges from about 650 feet at the Bowes oil and gas field to 1,050 feet at the Mule. Creek Oil Co. dry hole in sec. 23, T. 26 N., R. 20 E. (half a mile south of the south boundary of the Rattlesnake quadrangle). The variation in thickness is probably due to erosion that took place before the deposition of the overlying Sawtooth Formation.

\section{JURASSIC SYSTEM}

The Jurassic System in the Bearpaw Mountains is represented by the marine Ellis Group, of Middle and Late Jurassic age, whose lower contact with the Mission Canyon Limestone represents a major regional unconformity. In the recent mapping by the U.S. Geological Survey, the Ellis Group has been divided from bottom to top into three formations, as proposed by Cobban (1945): the Sawtooth Formation of Middle Jurassic age and the Rierdon and Swift Formations of Late Jurassic age. In the Bearpaw Mountains area the Morrison Formation of latest Jurassic age cannot be identified with any certainty; but if it is present, it is represented by 20-40 feet of dark-gray shale and tan sandstone.

\section{SAWTOOTH FORMATION}

The Sawtooth Formation is exposed only in the Suction Creek dome in secs. 1, 11, and 12, T. 28 N., R. 20 E. The formation is about 100 feet thick and is composed of three units, which were not mapped separately. The basal unit, 4 feet thick, is composed of light-gray fine-grained calcareous sandstone, siltstone, and conglomerate containing pebbles of fossiliferous chert derived from the underlying Mission Canyon Limestone. The medial unit, about 65 feet thick, is composed of dark-gray massive fossiliferous, locally oolitic, limestone beds separated by thin shaly beds. The upper unit, 30 feet thick; consists mainly of thin calcareous sandstone beds and a variety of gray laminated, thin-bedded, and massive sandy oolitic and fossiliferous limestone beds. A dark-bluish-gray wavy-bedded platy limestone layer 2-6 inches thick crops out at the top. Crossbedding, intraformational conglomerate, and minor unconformities in the upper unit are evidence of deposition in an environment of appreciable wave and current action. Insoluble residues in samples from one of the massive crossbedded sandy limestone beds made up 15-20 percent by weight of the rock. Limestones of the Sawtooth Formation release a petroliferous, fetid odor when struck. Pelecypods and sponges are abundant.

The Sawtooth Formation is referred to as the Piper Formation by some workers who deal with subsurface sections in north-central 
Montana. In the Bowes oil and gas field on the north flank of the Bearpaw Mountains, the Piper Formation has been divided into three members (Hunt, 1956, cf. Nordquist, 1955), upward : the Tampico Shale Member (calcareous shale), the Firemoon Limestone Member (dense limestone), and the Bowes Member (sandy limestone, calcareous sandstone, and shale). Petroleum is produced from the Bowes Member and the Firemoon Limestone Member. Lithologic correlations of the section of the Sawtooth Formation in the Suction Creek dome and the section in the Bowes field are as follows: The medial unit probably represents the Firemoon Limestone Member; the clastic limestone composing the upper unit probably represents the Bowes Member; and the lowest unit of the Sawtooth, the thin basal chert-pebble conglomerate and calcareous siltstone, probably represents the Tampico Shale Member.

Paleontologic correlations based on studies in this quadrangle and in other areas are given in the following written communication by Ralph W. Imlay (1964) :

The medial unit exposed in the SW1/4 SW1/4 sec. 1, T. 28 N., R. $20 \mathrm{E}$., in the Rattlesnake quadrangle, contains mollusks of Bajocian age. These include Gryphaea planoconvexa Whitfield (USGS Mesozoic locs. 8096 and 18757) and a new ammonite genus (USGS Mesozoic loc. 8096). Both these fossils have been found elsewhere only in beds of Bajocian age-including the middle limestone member of the Piper Formation in south-central Montana-in the lower and middle parts of the Sawtooth Formation in southwestern Montana, and in member $\mathbf{C}$ of the Twin Creek Limestone in Idaho and Wyoming. In addition, Gryphaea planoconvexa Whitfield has been obtained from cores near the middle of the limestone member of the Piper Formation at a depth of 2,896-2,906 feet in The Texas Co.'s Bowdoin unit 1 (822) in the SW1/4 SW1/4 sec. 8, T. 32 N., R. 32 E., Phillips County, Mont. In these cores it is associated with Gervillia montanaensis Meek, which has the same restricted stratigraphic range. The fossil evidence is strong, therefore, for correlating the middle member of the Piper Formation in both subsurface and surface sections with the medial unit of the Sawtooth (Piper) Formation exposed in the Bearpaw Mountains.

A section of the Sawtooth Formation is given below.

Section of Sawtooth Formation, Suction Creek dome, SW $1 / 4$ sec. 1 and NW1/4 sec. 12, T. 28 N., R. $20 \mathrm{E}$.

[Measured by B. C. Hearn, Jr., and R. A. Sheppard, Sept. 9, 1957]

Thicknese Ft in

Basal beds of Rierdon Formation:

Shale, calcareous, and argillaceous limestone; weather yellowish

gray to gray.

Sawtooth Formation :

Beds possibly equivalent to the Bowes Member:

Limestone, algal; has thin wavy laminations; weathers as dark-bluish-gray plates

Limestone, sandy, oolitic, gray ; insoluble residue 15 percent.- 10

Shale, calcareous, gray; contains thin oolitic-limestone beds_.- 13 
Section of Sawtooth Formation, Suction Creek dome, SW1/4 sec. 1 and NW1/4 sec. $12, T .28$ N., R. 20 E.-Continued

Sawritooth Formation-Continued

Beds possibly equivalent to the Bowes Member-Continued

Thickness

Ft in

Limestone, sandy, oolitic, rather homogeneous, gray; bedding uneven, some poor crossbedding; insoluble residue 17 percent; beds of argillaceous limestone make up less than 1 percent.

Limestone, sandy, gray; less sandy than unit above; contains some quartz-calcite vugs; top and bottom 3 in. contain a few thin argillaceous limestone beds having intraformational conglomerate and contorted bedding

Limestone: thin interbeds of light-gray impure limestone and tan sandy limestone or calcareous sandstone; character: ized by contorted bedding and intraformational conglomerates; some fossiliferous beds of abraded pelecypod shells and crinoid fragments-

Limestone, sandy, gray; rather homogeneous unit having indistinct beds about $1 \mathrm{ft}$ thick and crossbeds $1 / 4-1$ in. thick

Limestone, sandy, gray; less sandy than unit above; crystalline quartz in vugs; contains flakes and lumps of impure limestone

Limestone, sandy, massive, light-gray; indistinct uneven bedding

Limestone, sandy, massive, dark-gray, slightly oolitic; some crossbedding

Beds possibly equivalent to the Firemoon Limestone Member :

Limestone, interbedded impure silty and shaly, medium-gray and dark-gray; more fissile toward bottom

Limestone, slightly sandy; sand decreases toward bottom; weathers medium gray to dark bluish gray; massive; beds $1 / 2-12$ in. thick; 1 in. bed of shale or calcareous shale at base

Limestone, and interbedded thin shales and calcareous shales. Limestone is fine grained, massive, cliff forming, and weathers dark bluish gray; beds from 1 in. to $2 \mathrm{ft}$ thick, average $11 / 2 \mathrm{ft}$ thick; several highly fossiliferous zones. Shale weathers yellowish brown to gray; beds from $1 / 2-3$ in. thick; shale more abundant toward base.

Beds possibly equivalent to the Tampico Shale Member:

Limestone, sandy, and calcareous sandstone; massive; unit weathers white to dark gray

Sandstone, calcareous; weathers white; bedding platy, beds $1 / 2-2$ in. thick; contains rounded chert pebbles, derived from Mission Canyon Limestone, and crinoid fragments.

Limestone, conglomeratic, impure sandy; weathers white to light gray; contains chert pebbles, similar to those described above but less rounded, and limestone fragments.

Total thickness, Sawtiooth Formation 
Section of Sawtooth Formation, Suction Creek dome, SW1/4 sec. 1 and NW1/4 sec. 12, T. 28 N., R. 20 E.-Continued

Upper beds of Mission Canyon Limestone:

About $2 \mathrm{ft}$ of limestone intraformational conglomerate containing tabular limestone fragments, authigenic quartz crystals as much as 1 in. long, and chert nodules above alternate light-gray to white and medium- to dark-gray beds of highly fossiliferous limestone having abundant nodules and lenses of chert.

\section{RIERDON FORMATION}

The lower two-thirds of the Rierdon Formation consists mostly of yellowish-gray to medium-gray calcareous shale and thin-bedded argillaceous limestone but also includes a few resistant beds of more massive limestone. The upper third of the formation, which commonly forms a ledge or low cliffs, is massive to thin-bedded gray limestone and shaly limestone.

A complete section of the Rierdon Formation is exposed in this quadrangle only in the Suction Creek dome, where it measures 145 feet. The formation is thicker in the Taylor Butte dome in secs. 1, 2, 11, and 12, T. 28 N., R. 19 E. There 165 feet of the formation rests above the igneous core of the dome, but the base of the formation is not exposed. In other domes, exposures of the Rierdon are a few acres or less in area and are limited to the upper, more massive part of the formation. Fossils in the Rierdon Formation include ammonites, Belemnites, and pelecypods, especially Gryphaea nebrascensis Meek.

\section{SWIFT FORMATION}

In the Rattlesnake quadrangle the Swift Formation is from 140 to 170 feet thick. Three lithologic units can be distinguished, but they were not mapped separately. The lower two units are marine, and the upper unit represents the transition to the overling nonmarine Kootenai Formation of Cretaceous age. The lower unit, 50-85 feet thick, is dark-brown to gray slightly calcareous shale which contains a few beds of brown-weathering concretionary limestone and, locally, some discrete brown ovoid calcareous concretions having calcite and barite in septarian veins. This lower unit contains ammonites, abundant Belemnites and Gryphaea, and, locally, one or more beds of conglomerate composed of abraded Belemnites. The medial unit consists of about 30 feet of alternate thin beds of finely bedded brown fine-grained sandstone or siltstone and dark-gray shale, and the unit appears ribboned in outcrop. Worm burrows occur in the sandy beds. The upper unit, 40-60 feet thick, has approximately equal amounts of dark-gray shale and light-yellow to tan crossbedded sandstone in beds as much as 10 feet thick and, in its upper part, 
includes about 20-40 feet of beds which may be equivalent to the Morrison Formation of Late Jurassic age.

\section{CRETACEOUS SYSTEM}

The Cretaceous System in the Bearpaw Mountains comprises, from the base upward, the Kootenai Formation, Colorado Shale, Montana Group (which includes the Eagle Sandstone, Claggett Shale, Judith River Formation and Bearpaw Shale, in ascending order), Fox Hills Sandstone, and Hell Creek Formation. Beds of the Kootenai represent an interval of fresh- and brackish-water deposition which took place before the marine deposition of the Colorado Shale. In the Montana Group, marine conditions prevailed during the deposition of the shales; however, both marine and brackish-water environments prevailed during deposition of various parts of the Eagle Sandstone and the Judith River Formation. The Fox Hills Sandstone was the last marine unit deposited before the Cretaceous sea withdrew from this area. Deposition of the Fell Creek Formation of latest Cretaceous age was under essentially «onmarine conditions.

\section{KOOTENAI FORMATION}

The nonmarine Kootenai Formation is exposed in the center of several domes but is best exposed in the Suction Creek dome, where it is 240 feet thick, and in the Taylor Butte dome, where it is 200 feet thick. Although the lithology of the Kou,enai varies, the formation in general consists of a lower sandy, arkosic nonvariegated sequence and an upper variegated sandy, arkosic and silty sequence.

The nonvariegated basal part of the Kootenai Formation, 90-100 feet thick, is a sequence of brown to white crossbedded massive to platy sandstone, light-brown to gray siltstone, and minor gray shale; and it has a light-gray to white crossbedded medium- to coarsegrained resistant sandstone bed 12-15 feet thick in the upper part. This sandstone has a salt-and-pepper appearance because of abundant black chert grains, and it is equivalent to the "third Cat Creek sand," a unit used in subsurface sections by petroleum geologists. In some localities, as on the east and southeast sides of the Suction Creek dome, the salt-and-pepper sandstone and about 30 feet of beds above it contain lenses of conglomerate of well-rounded cobbles as large as 5 inches in diameter and pebbles of quartzite, chert, silicified limestone, and vein quartz. Fragments of crinoid stems and brachiopods in some pebbles suggest derivation from formations of Paleozoic age (E. L. Yochelson, written commun., 1954). The basal third of the formation contains plant fragments and silicified wood. Ferruginous claystone concretions which weather dark reddish brown occur near the base. 
The variegated, upper 100-150 feet of the Kootenai Formation consists mostly of red, purple, green, and tan siltstone and claystone and white, tan, and green arkosic crossbedded sandstone but includes a few thin beds of dark platy limestone in the lower part. The topmost 2 feet is a distinctive massive bed of tan to olive siltstone having a dark-brown to black stain on fracture surfaces. A distinctive "second Cat Creek sand" of the upper beds of the Kootenai in other regions is obscure or absent in this quadrangle. Reeves (1924a, p. 92) stated that a gray sandstone bed 5 feet thick 150 feet below the top of the formation is the " $* * *$ approximate horizon of second Cat Creek sand."

\section{COLORADO SHALE}

In the Bearpaw Mountains the Colorado Shale is mainly a dark-gray shale, but it contains numerous beds of sandstone, siltstone, bentonitic shale, claystone, and limestone concretions and a few beds of limestone. It has been divided following the suggestion of Cobban (1951, and later oral commun.) into eight members which are equivalent to, but somewhat different in lithology from, the long established formations of the Black Hills (Rubey, 1930). From the base upward these members are the Fall River Sandstone, Skull Creek Shale, Newcastle Sandstone, Mowry Shale, Belle Fourche Shale, Greenhorn Limestone, Carlile Shale and Niobrara Shale. In Central Montana the Telegraph Creek Member is also considered to be part of the Colorado Shale, although its equivalent in the Black Hills is above the Colorado Shale. The authors, following the suggestion of Reeside and Cobban (1960, p. 28-30), set the top of the Mowry Shale Member as the boundary between the Upper and Lower Cretaceous. Division of the Colorado Shale into eight mappable units has made possible the detailed mapping of the structural arch of the Bearpaw Mountains.

\section{FALL RIVER SANDSTONE MEMBER}

The Fall River Sandstone Member is 250-300 feet thick in this quadrangle and consists of an upper sandy part 40-70 feet thick and a lower part composed of black shale and sandstone.

The lower part is dominantly black shale, but it contains some thin olive to brown siltstone and sandstone beds and several layers of ferruginous claystone concretions that weather dark reddish brown. Phosphatic nodules (Pecora, Hearn, and Milton, 1962) occur in the basal 30 feet of the shale, and trail- and burrowlike casts are preserved in the thin sandstone and siltstone beds.

The upper 40-70 feet of the Fall River Sandstone Member is an irregularly bedded to crossbedded ledge-forming light-gray to tan 
sandstone having thin partings and beds of dark-gray shale. In most exposures the sandstone contains one or more distinctive beds or lenses of conglomerate consisting of smooth well-rounded black, brown, gray, white, and green pebbles averaging $1 / 4^{-1 / 2}$ inch in size and made up dominantly of chert; a few pebbles are vein quartz and quartzite. The maximum thickness observed for a single conglomerate bed in the quadrangle is 3 feet, measured in the central part of the dome in sec. 6, T. 28 N., R. $21 \mathrm{E}$.

Cobban (1951) correlated the "first Cat Creek sand" (about $35 \mathrm{ft}$. thick) at the base of the Colorado Shale in central Montana with the Fall River Sandstone of the Black Hills area. In the Bearpaw Mountains, however, the Fall River Sandstone Member has been mapped by the U.S. Geological Survey, on the basis of later examination of the Colorado Shale section in this area by Cobban (oral commun., 1952), to include beds higher than those possibly correlative with the "first Cat Creek sand." This correlation of the basal part of the Colorado Shale differs from that used by Knechtel (1959) in the Little Rocky Mountains area to the east. However, lithologic correlations between the Bearpaw Mountains and the Little Rocky Mountains are easily made. The Cyprian Sandstone Member (Knechtel, 1959) of the Thermopolis Shale in the Little Rockies is the same unit as the conspicuous chert-pebble sandstone assigned to the top of the Fall River Sandstone Member in the Rattlesnake quadrangle. The "first Cat Creek sand," which Knechtel was able to map separately, is poorly exposed or absent in the Rattlesnake quadrangle.

Imprints of Inoceramus bellvuensis Reeside are found in the lower part of the formation. W. A. Cobban (written commun., 1952) stated that this species of Inoceramus is indicative of Albian or latest Early Cretaceous age.

\section{SKULL CREEK SHALE AND NEWCASTLE SANDSTONE MEMBERS}

In the western Bearpaw Mountains the Skull Creek Shale Member can be mapped separately as black siliceous shale that lacks sandstone beds, in contrast to the Newcastle Sandstone Member which consists of dark-gray to black shale but has many thin sandstone, mudstone, and siltstone beds. In this quadrangle the two members have been grouped for mapping into a single unit inasmuch as they have somewhat similar lithology. The unit is mainly dark-gray to black shale but has numerous thin beds of drab to rusty-weathering sandstone, mudstone, and siltstone which locally are numerous enough to constitute several thin-bedded rusty units as much as 5 feet thick. The rusty color is probably due to weathering and alteration 
of glauconite and pyrite (Pecora and others, 1957). Some beds and concretionary lenses of iron-rich claystone are present, and locally one of the sandstone beds bears a thin layer of chert-pebble conglomerate. Imperfect pelecypod imprints are the only fossils found. The measured thickness south of Johnson Butte is 300 feet.

\section{MOWRY SHALE MEMBER}

The Mowry Shale Member is composed mainly of hard fissile platy finely laminated siliceous shale and fine-grained siltstone, but it also includes minor amounts of sandstone, bentonitic shale, and bentonite. The member weathers to a distinctive light bluish gray and forms a resistant rim around several domes. Abundant fish-scale imprints are characteristic. Local accumulations of fish skeletal debris, scales, and teeth form beds as much as 2 inches thick. Near the top of the Mowry, approximately at the level of the Clay Spur bentonite of the Hardin area, Montana, (Knechtel and Patterson, 1956) are either several beds of bentonite each as much as 6 inches thick or a single bed of bentonite as much as 5 feet thick, as on the west side of the Hansen Creek dome. Such a thick bed of bentonite in the Mowry may be the result of plastic flowage during folding. Measured thicknesses of the Mowry range from 65 to 80 feet. The upper and lower contacts are each gradational over an interval of about 5 feet.

\section{BELLE FOURCHE SHALE MEMBER}

The Belle Fourche Shale Member is predominantly black shale but contains some thin sandstone and siltstone beds and a conspicuous sandy sequence. In the basal 50 feet, distinctive ovoid iron- and manganese-rich claystone concretions which weather dark reddish brown and are commonly 1-3 feet in diameter occur in the black shale. The conspicuous sandy zone, which is $80-100$ feet above the base of the member, includes 5-30 feet of resistant irregularly bedded gray to tan sandstone having shaly partings and commonly one or more lenses 1-6 inches thick of black chert grit or fine-grained conglomerate. A zone of ovoid blue-gray to yellowish-gray calcareous septarian concretions that are as much as 6 feet in diameter occurs in the upper 30 feet. Thin beds of sandstone, siltstone, and bentonitic shale are present through most of the member. Fossils are rare in the Belle Fourche. The measured thickness in the dome south of Scotty Butte is 300 feet.

\section{GREENHORN LIMESTONE MEMBER}

The Greenhorn Limestone Member is an easily recognized sequence of limestone, siltstone, and shale 40-65 feet thick. The lower unit is medium-gray-weathering thin-bedded platy petroliferous sandy 
limestone (insoluble residue about 10 percent by weight) which has a fetid odor when broken. The medial part is dark-gray shale, and the upper part is thin-bedded slightly calcareous to noncalcareous siltstone and minor sandy limestone. The Greenhorn Limestone Member is highly fossiliferous; it contains abundant fish scales, shells and imprints of Inoceramus labiatus Schlotheim, and impressions of small ammonites.

\section{CARIILE SHALE AND NIOBRARA SHALE MEMBERS}

These members, which have a total thickness of about 750 feet, have been grouped as one unit for mapping because of their lithological similarity and because of the difficulty in separating them without extensive faunal evidence.

The Carlile Shale Member, lying immediately above the Greenhorn Limestone Member, is composed of black chippy siliceous shale and rare thin beds of siltstone and sandstone. In a zone near the base of the member, distinctive ovoid iron-rich claystone concretions and associated beds and lenses of similar lithology weather out in rusty orange chips. This zone is the "red chip zone" mentioned by Reeves (1924a, 1929). The Carlile is 200-250 feet thick. Fossils are rare.

The Niobrara Shale Member is 500-550 feet thick and is composed mainly of dark-gray to brownish-gray shale and siltstone but includes some thin beds of siliceous siltstone and sandstone and many thin beds of bentonitic shale and bentonite. Also in the Niobrara Shale Member are discontinuous concretionary limestone beds and ovoid to discoid massive to septarian calcareous claystone concretions that weather light gray to yellowish gray. The Niobrara Shale Member contains Baculites, Scaphites, fish scales, pelecypods, and fragments of large Inoceramus shells. The Niobrara grades upward into the Telegraph Creek Member.

\section{TELEGRAPH CREEK MEMBER}

The Telegraph Creek Member is the sequence of beds transitional between the Niobrara Shale Member and the Eagle Sandstone. The contact of the Telegraph Creek Member with the Niobrara is placed below the first recognizably coarser persistent thin bed of brownishgray siltstone and sandstone upward in the section, but this contact is difficult to locate with assurance and in many places can only be inferred. As mapped in the Rattlesnake quadrangle, the member is commonly about 150 feet thick. The lower part is composed of alternate thin beds of brownish siltstone, sandstone, and gray to brownish-gray shale that grade upward to a predominantly silty and sandy thin-bedded sequence having shale partings. Concretions are discoid gray to yellow calcareous and sandy claystone and are 
generally nonseptarian. In the Scotty Butte and Hansen Creek areas, a resistant yellowish-brown sandstone unit 10 feet thick is about 75 feet below the top of the member. In the Myrtle Creek area the upper part of the member contains small polished pebbles of black chert. Fossils are abundant and include Baculites, Scaphites, Inoceramus, and other pelecypods, and bone and fish fragments.

\section{MONTANA GROUP}

From oldest to youngest the Montana Group consists of the Eagle Sandstone, Claggett Shale, Judith River Formation, and Bearpaw Shale.

\section{EAGLE SANDSTONE}

The Eagle Sandstone, of marine to brackish water origin, is about 200 feet thick in the Rattlesnake quadrangle. The base of the unit is placed at the bottom of the first massive sandstone above the transitional lithology of the Telegraph Creek Member. Approximately the lower three-fourths is massive, or thick-bedded crossbedded cliff-forming yellowish-brown to white sandstone that contains numerous calcareous-sandstone concretions as much as 15 feet in diameter which weather reddish brown. In the lower three-fourths, shale and siltstone are subordinate. This part of the Eagle Sandstone is equivalent to the Virgelle Sandstone. Approximately the upper one-fourth of the Eagle consists of thick- and thin-bedded tan to white sandstone and thin-bedded brown to gray siltstone and shale. The shale is locally carbonaceous. The decreasing amount of sandstone upward through the upper one-fourth of the Eagle represents the transition to the Claggett Shale.

The transitional beds have three distinctive features, any of which may be absent locally: (1) well-rounded, polished, commonly discoid pebbles of black, brown, and greenish-gray chert as large as 1 inch in diameter occurring mainly in sandstone, (2) green grains of glauconite (?) in sandstone beds, and (3) thin beds of fine sandstone and siltstone which weather brick red. In some localities the lowest beds of the Claggett Shale also contain chert pebbles.

Reeves (1924a) reported the presence of thin beds of carbonaceous shale and coal in exposures along Cow Creek about 3 miles south of the Rattlesnake quadrangle. Southwest of the Bearpaw Mountains the upper part of the Eagle contains minable coal beds. In the Rattlesnake quadrangle, however, no coal beds have been found although rarely some thin partings of carbonaceous shale do occur. No fossils have been found, but to the north and west the formation contains oyster shells and abraded Baculites. 


\section{CLAGGETT SHALE}

The Claggett Shale in the Bearpaw Mountains is generally a rather homogeneous sequence of gray to brownish-gray fissile flaky shale and bentonitic shale which weathers brown; it is $450-550$ feet thick. Large ovoid to discoid calcareous septarian claystone concretions, most of which weather brownish yellow to orange, occur in several zones. Several thin beds of bentonite are present in the lower 100 feet of the formation, and locally the lower 20 feet may contain scattered chert pebbles. About 50-100 feet below the top of the formation in most exposures is a sandy zone, or locally two zones, of alternate thin beds of shale, siltstone, and sandstone; this zone has a central series of discontinuous more resistant crossbedded sandstone beds as much as 10 feet thick which contain calcareous sandstone concretions. The upper part of the Claggett, 30-50 feet thick, has a typical transitional lithology similar to that of the Telegraph Creek Member of the Colorado Shale. In many exposures, tabular nonseptarian concretions of calcareous siltstone occur in the transition beds. The upper contact of the Claggett Shale is mapped as the top of the transition sequence-below the first massive sandstone bed of the basal part of the Judith River Formation.

Pelecypods and two species of Baculites occur in the Claggett Shale but are not abundant.

\section{JUDITH RIVER FORMATION}

The Judith River Formation, of marine and brackish-water origin, is 500-600 feet thick and consists of sandstone, siltstone, claystone, shale, carbonaceous shale, and coal. Although the formation varies lithologically both horizontally and vertically from one locality to another, it can be divided into four members over much of the southern half of the quadrangle where it is well exposed.

The basal member, 100-150 feet thick, consists mainly of massive resistant yellow, buff, and white crossbedded sandstone containing calcareous-sandstone concretions that weather reddish brown and resemble those in the Eagle Sandstone. Thin beds of shale and carbonaceous shale are present.

The second member above the base is 300-350 feet thick and consists of intercalated gray, white, grayish-brown, and yellowishbrown lenticular sandstone, clayey sandstone, siltstone, shale, and a few thin beds of brown carbonaceous shale. Individual beds average 6-12 inches in thickness and give a banded appearance to good exposures. Calcareous sandstone and claystone concretions are abundant.

The third member above the base is about 100 feet thick and contains conspicuous beds of carbonaceous shale and coal and a distinctive bed of calcareous sandstone rich in oyster shells. These 
beds are interbedded with friable clayey sandstone and claystone. The upper part of this unit in much of the Cow Creek area consistently has three beds of brown carbonaceous shale 4-8 feet thick which contain central coal beds 1-4 feet thick. Lithified logs are not uncommon. Abraded oyster shells, concentrated in a sandstone bed which averages 6-12 inches in thickness, commonly occur near the uppermost coal in the Cow Creek area but higher or lower in the section elsewhere; locally these shells are absent or occur in more than one zone.

The uppermost member of the formation is as much as 50 feet thick and is composed of white to somber light-gray friable clayey sandstone containing numerous resistant concretionary siltstone beds and concretions, which weather bright orange to reddish brown, and minor bentonitic shale. At some localities, a thin transition zone of alternate gray to brown shale and light sandstone constitutes the top part of the member. Locally, as in the Winters Creek area, the uppermost member is thin, is entirely transitional in lithology, or is absent. Where the member is absent, the overlying Bearpaw Shale rests directly on the shell bed or carbonaceous shale and coal of the next lower member.

Marine fossils identified by W: A. Cobban (written commun., Dec. 23, 1959) -Placenticeras meeki Boehm in the uppermost member; pelecypods, of near-shore habitat; and Baculites sp. in the lowermost member-indicate that at least some of these beds were deposited in a marine environment. Disarticulated vertebrate bones and teeth are found in all members but are most abundant near the top of the second member. In several places, well-rounded pebbles and cobbles of diverse lithology occur in bone-bearing beds and may be gastroliths ("stomach stones") of reptilian vertebrates. G. Edward Lewis of the U.S. Geological Survey identified (written commun., May 3, 1960) several lots of vertebrate remains, which include the following forms:

Lamna sp.

Shark, genus and species indeterminate

Lepidosteus sp.

Aspideretes cf. A. foveatus (Leidy)

Champsosaurus sp.

Crocodilian, genus and species indeterminate

Theropod, genus and species indeterminate

Ornithopod, genus and species indeterminate

Palaeoscincus costatus Leidy

?Leurospondylus sp.

Three polished pebbles, possibly gastroliths

Fresh-water and brackish-water pelecypods and gastropods are common. 


\section{BEARPAW SHALE}

The Bearpaw Shale in Bearpaw Mountains is approximately 1,200 feet thick. It is dominantly fissile bentonitic and nonbentonitic shale which weathers medium gray to bluish gray and contains ovoid and discoid concretions.

The formation can be divided into three members (described below but not mapped separately) where it is well exposed, as in the southwestern part of the quadrangle in the Three Mile Ridge area and in the drainage basin of Als Creek:

1. Gray-weathering shale, 350-400 feet thick, which contains several conspicuous beds of yellowish-white to white bentonite and bentonitic shale as much as 2 feet thick, large septarian calcareous claystone concretions as much as 8 feet in diameter which weather yellowish-gray and are generally nonfossiliferous, and a few reddish-brown-weathering nonseptarian iron-rich claystone concretions.

2. Gray-weathering shale, 650-800 feet thick, which lacks thick bentonitic seams and generally has only few septarian concretions but which has numerous nonseptarian fossiliferous and nonfossiliferous calcareous claystone concretions. Many of the concretions are rich in iron and weather dark reddish brown; others weather light gray, grayish yellow, or brown. Several units in this member, each as much as about 30 feet thick, are more silty than the other units of the member and weather brownish-gray instead of the common gray color of weathered Bearpaw Shale.

3. Transition beds which form a sequence 70-130 feet thick of alternate brown-weathering brown to gray shale, and thin siltstone and sandstone beds; coarse-grained beds become more abundant upward in the section. The beds contain concretions of nonseptarian silty claystone, calcareous siltstone, and sandstone which weather yellow, brown, and reddish brown. This uppermost part is well exposed in sec. 9, T. 27 N., R. 20 E., along Winters Creek and in secs 1 and 12, T. 26 N., R. 19 E., in the Three Mile Ridge area.

On the basis of invertebrate fossils, principally Baculites, identified by W. A. Cobban, four faunal zones are recognized in the Bearpaw Shale in the Rattlesnake quadrangle (Cobban, 1962; written commun., Sept. 12, 1957, Dec. 23, 1959, Jan. 25, 1960). In the lowest zone, extending about 150 feet above the base of the formation, only one specimen, resembling Baculites corrugatus Elias (W. A. Cobban, oral commun., 1957), has been collected. In the next higher zone, about 150-300 feet above the base of the formation, Baculites cf. B. compressus Say robinsoni Cobban has been found. Thus the two lowest faunal zones of the Bearpaw practically coincide with the lowest member-that is, with the member which contains thick 
bentonite beds. In the next highest zone, about 350-800 feet above the base, a new species (Cobban, 1962)-Baculites cuneatus Cobban -has been found. The highest faunal zone, about $800-1,050$ feet above the base, contains Baculites reesidei Elias and the coiled cephalopod Rhaeboceras whiteavesi Landes. The upper 150 feet of the formation in the Lloyd quadrangle, adjoining the Rattlesnake quadrangle on the northwest, contains Baculites grandis Hall and Meek. Thus lithologic character and adequate collections of baculites permit subdivision of the Bearpaw Shale over large areas.

Other fossils are abundant in the Bearpaw Shale. Those collected include Placenticeras meeki Boehm, Acanthoscaphites sp., Inoceramus sp., many other pelecypods, and several gastropods (identified by W. A. Cobban, written commun., Dec. 23, 1959), and vertebrae of a mosasaur (identified by G. Edwards Lewis, written commun., May 3, 1960).

A section of the upper part of the Bearpaw Shale is given below:

Section of transition beds of upper part of Bearpaw shale along east side of Winters Creek in $S W 1 / 4$ sec. 9, T. 27 N., R. $20 \mathrm{E}$.

[Measured by B. C. Hearn, Jr., W C Swadley, C. J. Bowser, and N. K. Hagen, July 2i, 1959]

Fox Hills Sandstone, basal bed :

Feet

Sandstone, light tan; contains shaly partings_._.................. 10

Bearpaw Shale:

Transition beds :

Sandstone, yellowish-brown; in thin beds as much as $2 \mathrm{ft}$ thick, but averaging 6 in., which alternate with gray to brown shale; contains light-yellowish-brown finely bedded calcareous siltstone concretions at top and 1-2 ft of tan calcareous concretionary sandstone at bottom

Sandstone and shale, alternating; similar to above unit but sandstones are thinner and less abundant; thin-bedded concretionary sandstone layer 1-2 ft thick at bottom.

Shale and silty shale, gray to brownish-gray; silt content increases upward; about $30 \mathrm{ft}$ above base are reddish-brown chippy-weathering nonseptarian siltstone concretions; lower $20 \mathrm{ft}$ contains brown-weathering sandy siltstone concretions.-

Total thickness, Bearpaw Shale transition beds

Shale, gray, bentonitic and nonbentonitic, typical lithology of Bearpaw Shale.

\section{FOX HILS SANDSTONE}

The Fox Hills Sandstone is 80-90 feet thick and is mainly light-tan to light-yellow thick-bedded sandstone containing discoid to ovoid brown-weathering calcareous sandstone concretions and a minor amount of brownish-gray shale. Indeterminate leaf fragments and marine fossils, including the invertebrate Inoceramus fibrosus (Meek and Hayden), have been found in concretions in the formation 
elsewhere in the Bearpaw Mountains (Pecora and others, 1957), but no fossils have been found in the Fox Hills Sandstone in this quadrangle. Here there is no evidence of the unconformity recognized in eastern Montana at the top of the Fox Hills Sandstone. The Fox Hills Sandstone is well exposed in secs. 9 and 16, T. 27 N., R. 20 E., along Winters Creek and its eastern tributary.

A section of the Fox Hills Sandstone is given below:

Section of the Fox Hills Sandstone along eastern tributary of Winters Creek in. NE1/4 sec. 16, T. 27 N., R. $20 \mathrm{E}$.

[Measured by B. C. Hearn, Jr., W C Swadley, C. J. Bowser, and N. K. Hagen, July 21, 1959]

Hell Creek Formation, basal beds :

Feet

Coal and carbonaceous shale; 8 in. of brown carbonaceous sandstone at base

Fox Hills Sandstone:

Sandstone, massive; weathers white, light tan, and yellowish tan; brown-weathering sandstone concretions 20 and $40 \mathrm{ft}$ below top; at base, thin layer of concretionary siltstone which weathers reddish orange

Sandstone, massive; light-tan; beds 6 in. to $2 \mathrm{ft}$ thick, separated by thin brownish-gray shale layers which increase in abundance downward; a minor amount of small reddish-brown chippy siltstone concretions occur throughout unit.

Sandstone, massive; light-tan to light-yellow; contains a few rusty sandstone concretions

Sandstone, thin-bedded, light-tan; contains thin beds of brownishgray shale and orange-weathering silty concretionary layers_----

Sandstone, massive, light-tan; contains a few "cannonball" concretions about 6 in. in diameter

Total thickness Fox Hills Sandstone.

Bearpaw Shale:

Transition beds: interbedded gray to brown shale, silty shale, and light-tan siltstone and sandstone containing some brown silty and sandy calcareous concretions and thin red-orange concretionary siltstone layers.

\section{HELL CREEK FORMATION}

The Hell Creek Formation is preserved only in downdropped fault blocks. The formation in the Rattlesnake quadrangle is a series of sandstone, siltstone, claystone, bentonitic clay, carbonaceous shale and coal.

The lower half of the formation has three distinctive lithologies:

1. Carbonaceous shale, coal, and brown carbonaceous sandstone and siltstone, which mark the base and contain plant fragments identified by J. A. Wolfe (written commun., Dec. 5, 1960) of the U.S. Geological Survey as "Ficus" ceratops Knowlton, a species $733-904-64-4$ 
known only from the Hell Creek Formation and its age equivalents.

2. Beds $2-4$ feet thick of dark-gray to black carbonaceous bentonitic clay.

3. Subspherical, knobby silty calcareous concretionary nubbins, commonly $1 / 4-1$ inch in diameter, which weather creamy white to reddish brown and locally have coalesced to form discontinuous concretionary ledges.

The contact of the Hell Creek Formation with the overlying Fort Union Formation is difficult to place with assurance in some exposures. In several localities along Cow Creek, the contact has accurately been placed below typical beds of the Fort Union Formation-massive sandstone and abundant thin carbonaceous shale beds containing characteristic fossil plants. In the area of the measured section given below, about 240 feet of beds exhibits characteristics of both the Fort Union and Hell Creek Formations, and no fossils have been found to clarify the boundary. Vertebrate fossils, common in the Hell Creek Formation in eastern Montana, have not been found in this area.

The section of the Hell Creek Formation given below is a continuation of the section described for the Fox Hills Formation.

Section of Hell Creek Formation along eastern tributary of Winters Creek in $N E 1 / 4$ sec. 16 and $S E 1 / 4$ sec. $9, T .27 N$., R. $20 \mathrm{E}$.

[Measured by B. C. Hearn, Jr., W C Swadley, C. J. Bowser, and N. K. Hagen, July 21, 1959]

Fort Union Formation, basal beds :

Feet

Sandstone, massive, $\tan$ to light-yellow; contains brown sandstone "cannonball" concretions" and conspicuous thin orange concretionary siltstone layers; 5 -ft zone $16 \mathrm{ft}$ above base contains transported coal fragments; 1-ft bed of gray claystone occurs $6 \mathrm{ft}$ above base

Hell Creek Formation:

Claystone, thin-bedded, green and gray, and tan siltstone

Claystone, light-gray; contains dark rusty concretionary chips.-.-

Claystone, green, gray, tan; contains two thin carbonaceous clay zones which weather slightly purplish gray; some thin-bedded siltstone and dark rusty chippy concretionary zones

Sandstone and siltstone, thin-bedded, tan; contains some gray and brown claystone.

Claystone, gray, and gray to green shale and light-tan to light-yellow sandstone in beds 6 in. to $7 \mathrm{ft}$ thick; brown sandstone concretions occur in the thicker beds; unit contains 14 beds of carbonaceous shale and has a minor amount of coal in beds which average 6 in. thick but which are as much as $3 \mathrm{ft}$ thick; 6-in. bed of carbonaceous shale and coal occurs at top

Clay, brown, bentonitic; crops out as "popcorn" crust over loose powder; dark-gray carbonaceous clay $1 \mathrm{ft}$ thick at top. 
Section of Hell Creek Formation along eastern tributary of Winters Creek in $N E 1 / 4$ sec. 16 and $S E 1 / 4$ sec. $9, T .27 N ., R$. 20 E.-Continued

Hell Creek Formation-Continued

Feet

Sandstone, massive, light-gray-brown; contains large brown sandstone concretions.

Claystone, green, and finely bedded sandstone and siltstone; contains some rusty chippy concretionary siltstone beds; a conspicuous zone, as much as $1 \mathrm{ft}$ thick, of calcareous nubbins which weather reddish orange occurs at the top

Clay, bentonitic, brown to gray; crops out as "popcorn" crust over loose powder; upper $2 \mathrm{ft}$ is black and carbonaceous_._-...-

Sandstone, light-tan; has cream-weathering nubbin zone at top--.----

Clay, green, bentonitic; powdery below surface

Claystone and shale, greenish gray; contains abundant creamweathering nubbins in a 2 -ft thick zone at top and in a thin zone at bottom.

Clay, carbonaceous, bentonitic, dark-gray, and brown powdery clay

Sandstone, light-tan to light-yellow; contains a few thin layers of rusty, orange-weathering concretionary siltstone and small "cannonball" or potato-shaped brown sandstone concretions.-.-.-.--

Claystone, gray to greenish-gray; interbedded with light-gray siltstone and a minor amount of light-gray to light-yellow sandstone; includes four beds of dark-gray carbonaceous bentonitic clay as much as $2.5 \mathrm{ft}$ thick.

Claystone, gray to greenish-gray; in part slightly carbonaceous; interbedded with light-gray to gray siltstone and a minor amount of light-yellow sandstone and gray shale; nubbins, most of which weather cream colored but a few of which weather brown, are abundant in 10 zones as much as $4 \mathrm{ft}$ thick

Sandstone, friable, light-tan to light-yellow, poorly exposed; contains some gray claystone and shale

Claystone, medium-gray, slightly carbonaceous; includes some gray siltstone containing chippy red-orange-weathering concretionary siltstone layers

Sandstone, massive, light-tan to light-yellow; contains a few irregular sandstone concretions.

Siltstone and fine-grained sandstone, thin-bedded, light-gray to tan; contains small reddish-brown chippy-weathering sandstone concretions

Sandstone, yellow, and siltstone and claystone; 3 -inch bed of yellow bentonitic clay at top of unit

Shale, brown, carbonaceous, and a minor amount of coal; "Ficus" ceratops Knowlton (J. A. Wolfe, written commun., Dec. 5, 1960) found in lower part

Shale, gray, siltstone, and fine-grained sandstone

Shale, brown, carbonaceous, and a minor amount of coal; 8 in. of dark-brown carbonaceous sandstone at bottom

Total thickness, Hell Creek Formation 


\section{TERTIARY SYSTEM}

The Tertiary System is represented by the Fort Union Formation of Paleocene age, the Wasatch Formation of early Eocene age, and high-level pediment gravels (described in the section on surficial deposits). Although both the Wasatch and Fort Union Formations are absent from the surrounding plains, their occurrence in downfaulted blocks around the entire Bearpaw Mountains area establishes both formations as part of the regional sedimentary section of north-central Montana.

Red, pink, and orange sand-size grains of quartz, quartzite, and argillite are a characteristic feature of many sandstone units of the consolidated Tertiary formations. In general, these colored grains are more abundant in the coarse-grained sandstones, are absent from some fine-grained sandstones, and increase in abundance upward in the section. These grains do not occur in Cretaceous sandstones, and in the Bearpaw Mountains their presence is a diagnostic criterion of Tertiary formations.

\section{FORT UNION FORMATION}

The Fort Union Formation in the Bearpaw Mountains is approximately 1,150-1,300 feet thick and is composed of interbedded massive sandstone, thin- and thick-bedded siltstone and claystone, and thinbedded shale, carbonaceous shale and coal.

The bottom contact is difficult to place with certainty in some areas because of similarities between beds of the Hell Creek and Fort Union Formations. In the Cow Creek area, in sec. 18, T. 27 N., R. 20 E., a prominent and conspicuous massive sandstone and the beds of claystone, carbonaceous shale, and siltstone 10-20 feet below the massive sandstone (and near the base of the Fort Union Formation) contain a Paleocene flora. This flora comprises Metasequoia occidentalis (Newberry) Chaney, Cercidiphyllum arcticum (Heer) Brown, Platanus haydeni Newberry, and Viburnum antiquum Newberry ( $J$. A. Wolfe, written commun., Dec. 22, 1959). Thus, in the Cow Creek area the contact is placed below these plant-bearing beds and above claystones 50 feet lower in the section, containing abundant concretionary nubbins so typical of the Hell Creek Formation. The upper one-fourth of the Fort Union Formation contains abundant irregular rounded calcareous concretionary nubbins similar in form to those in the Hell Creek Formation.

The following section continues those of the Fox Hills Sandstone and Hell Creek Formation listed above and is representative of the Fort Union Formation in the Rattlesnake quadrangle: 
Section of Fort Union Formation along eastern tributary of Winters Creek in SE1/4 sec. 9, T. 27 N., R. $20 \mathrm{E}$.

[Measured by B. C. Hearn, Jr., W C Swadley, C. J. Bowser, and N. K. Hagen, July 21, 1959]

Wasatch Formation, basal beds:

Feet

Claystone, bentonitic claystone, siltstone, and shale, red, pink, purplish-gray, white, and greenish-gray; minor amount of sandstone; pink claystone bed at base.

Fort Union Formation:

Siltstone, claystone, and shale, light-gray, greenish-gray and lightJellow; minor amount of light-tan sandstone having calcareous concretions; eight zones as much as 2 feet thick contain brown to cream weathering concretionary nubbins; 1-ft beds of carbonaceous shale and coal occur 32 and $60 \mathrm{ft}$ below top

Sandstone, massive, light-tan; "cannonball" concretions

Claystone, green, gray, light-tan; contains cream and rusty-weathering concretionary nubbins which have locally coalesced into rusty calcareous concretionary lenses_.

Sandstone, light-yellow to light-tan; "cannonball" concretions

Claystone, light-gray, light-yellow, and greenish-gray, and some light-tan to light-gray sandstone beds; cream- to rusty-weathering calcareous nubbins and concretionary lenses in five zones, one of which is as much as $3 \mathrm{ft}$ in thickness; lowest zone of abundant nubbins in Fort Union is in basal part of this unit; 1.5ft bed of carbonaceous shale and coal $44 \mathrm{ft}$ below top, and two carbonaceous shales 6 in. thick 27 and $31 \mathrm{ft}$ above base-..---_---

Claystone, light-yellow and greenish-gray-

Claystone, gray; carbonaceous shale and coal in 1-ft bed at top and 2 -ft bed at base

Sandstone, light-tan; contains reddish silty concretions

Claystone, gray and green, and white siltstone; contains muscovite flakes and rusty siltstone concretions; 6-in. bed of carbonaceous shale and coal $16 \mathrm{ft}$ below top, 1 - $\mathrm{ft}$ bed of carbonaceous shale $6 \mathrm{ft}$ above base, $4 \mathrm{ft}$ of coal at base of unit.

Sandstone, massive, light-tan and light-yellow; contains discoid and "cannonball" concretions of brown sandstone and a few rustyorange chippy concretionary siltstone layers

Sandstone, light-tan and yellow; beds $3-8 \mathrm{ft}$ thick; contains some green and gray claystone and shale; carbonaceous shale in three thin beds in upper $55 \mathrm{ft}$ and in 1.5-ft bed $55 \mathrm{ft}$ below top.-.......-

Sandstone, massive, light-yellow to light-tan; contains brown sandstone concretions and rusty-orange chippy siltstone concretions

Sandstone, yellow to tan, thin- to medium-bedded, and gray shale and claystone; top $3 \mathrm{ft}$ is sandstone containing fragments of coal, next $3 \mathrm{ft}$ is coal which has been mined here (symbol on map) ; four thin carbonaceous shale layers in unit............-

Sandstone, massive, light-tan to yellow; contains brown sandstone concretions and chippy orange siltstone concretions; $1-4$ $\mathrm{ft}$ of green claystone $34 \mathrm{ft}$ above base. 
Section of Fort Union Formation along eastern tributary of Winters Creek in $S E 1 / 4$ sec. 9, T. 27 N., R. 20 E.-Continued

Fort Union Formation-Continued

Claystone, tan, gray, green, and minor amounts of pinkish-white; minor amount of thin bedded tan to yellow siltstone and finegrained sandstone and two thin beds of carbonaceous shale; pinkish-white claystone occurs in two beds, each 1-ft thick, and as thin interbeds in another zone 5-ft thick; thin bed of creamcolored nubbins occurs $50 \mathrm{ft}$ above base

Feet

Claystone, interbedded black, pinkish-white, and green

Sandstone, massive, light-yellow and tan; contains brown sand stone concretions

Claystone, dark-gray, gray, and brown; 6-in. bed $10 \mathrm{ft}$ below top is pinkish-white; minor amounts of thin-bedded siltstone and yellowish-tan sandstone.

Sandstone, massive, light-yellow to tan; contains brown sandstone concretions; thin zone of transported coal fragments $6 \mathrm{ft}$ above base ; 1-2 ft of coal at base

Sandstone, fairly massive; contains concretions of brown sandstone and thin orange siltstone; white to rusty transported nubbins or clay galls occur in lower $1 \mathrm{ft}$

Claystone, green, gray, and tan; cream- to rusty-weathering nubbins in uppermost $1 \mathrm{ft}$

Sandstone, massive, $\tan$ to light-yellow; contains brown sandstone "cannonball" concretions and conspicuous thin orange concretionary siltstone layers; 5 -ft zone $16 \mathrm{ft}$ above base contains transported coal fragments; 1 ft of gray claystone occurs $6 \mathrm{ft}$ above base

Total thickness, Fort Union Formation

1,141

\section{WASATCH FORMATION}

The Wasatch Formation occurs only in downfaulted and downwarped blocks. Parts of the formation are fairly well exposed in sec. 6, T. 27 N., R. 21 E.; secs. 2, 3, and 9, T. 27 N., R. 20 E.; and sec. 14, T. 26 N., R. 19 E.

The formation consists of poorly bedded red, pink, purple, green, and white claystone and shale and white, tan, green, and gray siltstone, sandstone, and conglomeratic sandstone. The base is placed below the lowest red or pink claystone bed. White-, pink-, and rusty-weathering calcareous concretionary nubbins occur in the claystone. The sandstone is arkosic, and some of it contains biotite flakes. Near the top of the formation, sandstone beds are poorly sorted and contain abundant sand-size fragments of argillaceous rocks. Well-rounded pebbles, cobbles, and small boulders form channel lenses in the upper part of the formation. In composition, these conglomerate lenses range from 50 to 80 percent argillite and quartzite, derived from rocks of the Belt Series; 20 to 40 percent fine-grained and porphyritic igneous rocks; 1 to 5 percent limestone 
of Paleozoic age; and less than 1 percent chert and conglomerate. At many localities the pebbles and cobbles are characteristically fractured and recemented. A decrease in average size and changes in lithology of pebbles and cobbles-for example, a decrease in percentage of limestone clasts eastward across the Bearpaw Mountains-indicate derivation from the west and southwest by erosion of the main range of the Rocky Mountains shortly after it was uplifted.

The fresh-water pelecypod Unio is the only fossil found in the Wasatch beds in this quadrangle. Elsewhere in the Bearpaw Mountains, leaves and other plant remains (Brown and Pecora, 1949) and vertebrate remains indicate an early Eocene age for the formation.

The total thickness of the formation is probably more than 650 feet. The following section, incomplete and in part poorly exposed where measured, continues those given under the Fox Hills Sandstone, Hell Creek Formation, and Fort Union Formation:

\section{Section of Wasatch Formation along the eastern tributary of Winters Oreek, NE1/4 SE1/4 sec. 9, T. 27 N., R. $20 \mathrm{E}$.}

[Measured by B. C. Hearn, Jr., W C Swadley, C. J. Bowser, and N. K. Hagen, July 21, 1959]

Fault against Claggett Shale at top of section.

Wasatch Formation (top missing or covered by terrace gravel) :

Feet

Covered by debris from terrace gravel.

Claystone, light-gray to brown, bentonitic in lower part of unit; contains chippy siltstone concretions; remainder is poorly exposed and consists of pink, white, and light-yellow clayey soil having some dark soil derived from coal or carbonaceous shale.

Poorly exposed; light-colored soil-

Siltstone and claystone, brownish-gray, poorly exposed, and exposed light-tan sandstone

Claystone, white, greenish-gray and gray ; contains a few pink beds; brown fine-grained sandstone and siltstone near middle

Claystone, bentonitic, white, green, gray, and red; red beds not abundant; minor amount of sandstone and shale; 10-15 ft of massive light-yellowish-tan sandstone at top contains brown sandstone concretions, "cannonball" concretions, and scattered pebbles of argillite and quartzite

Claystone, bentonitic, red, pink, purple, white, gray, and green; beds 1-20 ft thick, average $4 \mathrm{ft}$ thick; minor amount of sandstone; several beds of red, pink, and white calcareous concretionary nubbins; basal bed is red clayey siltstone

Exposed incomplete thickness, Wasatch Formation

665

\section{SURFICIAL DEPOSITS}

Surficial deposits in the Rattlesnake quadrangle are, from oldest to youngest, pediment gravels of Pliocene(?) age, a rockslide deposit 
and terrace gravels of Pleistocene(?) age, glaciofluvial deposits of Pleistocene age, and landslide deposits and alluvium of Recent age. The pediment and terrace gravels cover wide areas of benchland in the southern and eastern parts of the quadrangle, and they occur as isolated remnants along the northern border. The extensive cover of ground moraine which is present on the north and west sides of the Bearpaw Mountains does not occur here.

\section{TERTIARY SYSTEM \\ PEDIMENT GRA VELS}

The pediment gravels cover remnants of a high-level erosion surface at elevations of 4,000-4,500 feet near the mountains and $3,500-4,000$ feet in the plains and are correlated on the basis of elevation. Prominent examples of these gravel covered remnants are Three Mile Ridge and the benches southwest of Rattlesnake Butte and south of Logan Creek.

Near the mountain front the deposits are composed of poorly sorted pebbles, cobbles, and boulders ranging from 1 inch to more than 3 feet in diameter; but toward the plains size decreases. The components of the gravel are locally derived resistant rocks, such as baked shale and sandstone, hornfels, and the harder intrusive and volcanic rocks. The deposits are commonly 10-30 feet thick, but in some places they are as much as 80 feet thick.

In secs. 18, 19, and 30, T. 28 N., R. 21 E., and to the west, somewhat rounded boulders of intrusive porphyritic latite as large as 25 by 25 by 15 feet occur scattered within and near pediment gravel deposits. The boulders have been derived from the intrusive rocks as much as 1 mile distant to the west. The extreme size of the boulders indicates some catastrophic mode of transport, perhaps by landslide, during deposition of the high-level gravels in the area.

The high-level deposits in the Bearpaw Mountains cover the No. 1 bench of Alden (1932, p. 12-20), who correlated the deposits with the Flaxville Formation to the north near the Saskatchewan border. The Flaxville Formation contains fossil remains of mammals of Miocene-Pliocene age (Collier and Thom, 1918; Alden, 1932, p. 13-14). No fossils have been found in high-level deposits in the Bearpaw Mountains.

\section{QUATERNARY(?) SYSTEM}

\section{MYRTLE BUTTE ROCKSLIDF}

This unit is represented only in the area east of Myrtle Butte, where it covers about $13 / 4$ square miles. The deposit is tonguelike in 
gross form. On the surface there are numerous depressions, small knobs and ridges, and scattered blocks, the largest of which is 30 by 15 by 10 feet, and many of which are 4-8 feet long. All the blocks are intrusive porphyritic latite identical with that of the Myrtle Butte intrusion. In the only good exposure the deposit is composed entirely of unsorted angular blocks of porphyritic latite which average 3 feet in diameter, are ovoid in shape, and are chaotically arranged in an openwork fabric. The deposit is only 10-30 feet thick at its eastern and southeastern limits, but the maximum thickness in the central part may be more than 200 feet. It is older than the overlying terrace gravels and, as evidenced by its low elevation, is younger than the high-level pediment gravels. The deposit is interpreted as a major rock slide from the face of Myrtle Butte.

\section{TERRACE GRA VELS}

Remnants of as many as six gravel deposits, each capping a different terrace level, have been mapped in the Rattlesnake quadrangle. The gravel deposits are preserved as terraces and mesas, are poorly sorted, are composed of locally derived material ranging in size from sand to boulders, and are commonly from 5 to 15 feet thick. In lithology they are similar to the pediment gravel. Conspicuous rocks 3-9 inches in diameter cover the surface; many of these are tabular owing to initial sheeting of the igneous rocks and bedding of the sedimentary rocks. The gravels are cemented only locally, as on the No. 3 surface south of Myrtle Creek, but many fragments are covered by a white calichelike calcium carbonate crust. Formation of many of the erosion surfaces and terrace deposits was probably controlled by the mechanism of successive piracy of the main mountain streams by their tributaries. The process was well described by Hunt (1953) in his studies of the Henry Mountains area, Utah, and was thought by Knechtel (1953) to be applicable to the pediments around the Little Rocky Mountains, Mont.

Successively lower and younger deposits, correlated on the basis of elevation, are numbered from one to six on the geologic map. Areas within which remnants of these deposits can be correlated are successively more restricted for the lower levels, and thus correlation of the lower levels (below deposit 2) is only valid within single drainages or groups of drainages, as follows:

a. People Creek

b. Upper Gap Creek and Lewis Creek

c. Cow Creek, Hedges Creek, Als Creek, Bullwacker Coulee, lower Gap Creek, Coal Mine Coulee, Hansen Creek, and Winters Creek

733-904-64- -5 

d. Tin Cup Creek
e. Rattlesnake Creek and Spring Coulee
f. Suction Creek and Logan Creek
g. Myrtle Creek

The higher levels, deposits 1 and 2, can be correlated within each of the three main drainage basins: 1, Peoples Creek; 2, Cow Creek and its tributaries ( $\mathrm{b}$ and $\mathrm{c}$ above); and 3, Suction Creek and its tributaries ( $d, e, f$, and $g$ above). They have been tentatively correlated between the Cow Creek and Suction Creek basins.

The highest terrace deposits in part are those shown by Alden (1932) as the "No. 2 bench" and classified by him as early Pleistocene in age. Around the Bearpaw Mountains the lowest deposits of terrace gravels are overlain by glacial deposits and are thus preglacial. In this quadrangle, glaciofluvial deposits overlie the No. 5 terrace gravel in the northeast corner and the No. 4 terrace gravel along the lower part of Tin Cup Creek. No fossils have been found in the terrace gravels in the Bearpaw Mountains.

\section{QUATERNARY SYSTEM}

\section{GLACIOFLUVIAL DEPOSITS}

The glaciofluvial deposits are Pleistocene (probably Wisconsin) in age and consist mainly of silty or clayey sand and well-sorted, well-rounded cobbles and pebbles of quartzite, chert, and other resistant rocks typical of and derived from the high gravel plains of southern Alberta and Saskatchewan. Minor constituents include boulders, pebbles, and cobbles of granitic and metamorphic rocks derived from the Canadian shield area and pebbles and cobbles of igneous rocks derived from the Bearpaw Mountains. The maximum thickness is about 10 feet.

The glaciofluvial gravels in the northeast corner of the quadrangle were deposited on the west side of a melt-water channel, a wide flatfloored valley which leaves the Peoples Creek Valley near McCann Butte in the Cleveland quadrangle (Schmidt, Pecora, and Hearn, 1964) and extends southeastward several miles in a meandering course to join the present valley of Suction Creek east of the Rattlesnake quadrangle. This channel was a main outlet for melt water from the wasting continental glacier and approximately marks the southwestward limit of advance of the glacier on the east flank of the Bearpaw Mountains. The valley is floored by about 6 feet of clayey alluvium, beneath which is water-bearing gravel mainly composed of pebbles derived from the Bearpaw Mountains; some of the pebbles were brought to this area by the glacier.

The glaciofluvial gravels in the drainage of Tin Cup Creek contain 
some sand and silt and occur as thin veneers and isolated patches. Because of their restriction to elevations below about 3,240 feet and because of the lack of conspicuous channel features, it is believed that some of these gravels were dropped from floating ice in a short-lived glacial lake ponded by blockage to the southeast in the valley of Suction Creek. Some gravels were probably also deposited or reworked during drainage of the lake. The lake covered about 7 square miles in the south-central part of T. 27 N., R. 21 E., in the Rattlesnake quadrangle.

\section{RECENT LANDSLIDE DEPOSITS}

Only the larger areas of landslide deposits have been mapped. They are of Recent age, and several may have occurred within historic time. The deposits are unsorted, jumbled, and distorted masses of blocks and fragments derived from gravel deposits and from igneous and sedimentary rocks. The surfaces of the deposits characteristically have steep faces at the downslope margins and produce a hummocky topography having closed depressions. The slides, which represent both slump and rockslide movement, have occurred where resistant material, such as porphyritic latite or terrace gravel, overlies less resistant rocks, such as bentonitic shale.

In secs. 32 and 33, T. 28 N., R. 20 E., landslide material derived from the latite sill at the top of a hill makes up about one-third of a square mile of scarred topography on the southern slope. Although about 90 percent of the exposed extent of the sill has slid, individual blocks may not have moved more than 200 feet.

Two deposits, one north of Wilson Desert and one north of Myrtle Butte, are composed entirely of latite blocks as much as 15 feet in diameter from the adjacent intrusions. The slide north of Myrtle Butte may represent a more recent event of the type which produced the older and more extensive rockslide deposit to the east and southeast of Myrtle Butte.

The landslides east and northeast of Suction Butte are composed of fragments of intrusive porphyritic latite and fragments of rock from the Swift and Rierdon Formations. The landslides have in part moved down valleys. On the west end of Three Mile Ridge and the north side of Runyan Bench, pediment and terrace gravels and part of the underlying Bearpaw Shale have slid. South of Als Creek, in secs. 8 and 9, T. 26 N., R. 20 E., two landslide deposits consist of blocks of syenite derived from the adjacent remnants of sills and include fragments of Bearpaw Shale.

\section{ALLUVIUM}

Alluvium is of Recent age and is mapped only where it constitutes a major cover of the bedrock, as in the valleys of major drainages. 
The alluvium consists of locally derived poorly sorted to well-sorted gravel, sand, and silt. The usual thickness is 5-20 feet, but alluvium along the lower part of Cow Creek is as much as 40 feet thick.

\section{IGNEOUS ROCKS}

Igneous rocks cover about 22 square miles, or 11 percent, of the Rattlesnake quadrangle. Intrusive bodies are both more abundant and larger in the northern part of the quadrangle than in the southern part. Flows and pyroclastic deposits preserved within fault blocks in the central part of the area are remnants of a formerly more extensive southern volcanic field. The geologic age of the volcanism as determined from plant fossils in adjoining quadrangles is middle and early late Eocene.

In this report, the nomenclature of the igneous rocks conforms with that in recently published reports on the Laredo, Shambo, Centennial Mountain, Warrick, Maddux, Lloyd, and Cleveland quadrangles. However, some of the igneous rocks differ in petrographic detail from those in other parts of the mountains.

The chemical composition of the igneous rocks ranges from subsilicic alkalic to silicic alkalic. Varieties in the subsilicic-alkalic family contain feldspathoids and one feldspar (potassic feldspar), augite, biotite, and olivine; these varieties are commonly mafic and lack hornblende. Varieties in the silicic-alkalic family contain two feldspars(plagioclase and potassic feldspar), augite, hornblende, biotite; are commonly felsic; and lack olivine. Each family has both intrusive and extrusve representatives. Varieties intermediate between the two families contain neither feldspathoids nor quartz.

Petrographic and chemical data for five igneous rocks in the Rattlesnake quadrangle are assembled in table 1. Data for other igneous rocks in the mountains are recorded in earlier publications. The rocks in table 1 have intermediate contents of silica and alkalies as compared with the known suite from the Bearpaw Mountains and therefore are not representative of the extreme range of composition of that suite.

In this quadrangle, feldspathoidal rocks are rare, and most of the quartz-free alkalic rocks are shonkinite to syenite. Among the volcanics, however, mafic analcime phonolite (chemically equivalent to nepheline shonkinite) is abundant. Porphyritic quartz latite is the most abundant silicic-alkalic variety. Inclusions of Precambrian basement rocks are abundant in latitic rocks in the Bearpaw Mountains and are common also in a few shonkinite and syenite intrusions in this quadrangle. 


\section{INTRUSIVE ROCKS}

Intrusive igneous rocks made up about 17.5 square miles, or 9 percent, of the Rattlesnake quadrangle and occur in both sedimentary and volcanic terranes. Four mapping units are recognized: (1) shonkinite, (2) syenite and mafic syenite, (3) porphyritic latite, and (4) porphyritic syenite. Most intrusions are simple in their composition and have the form of dikes, plugs, sills, stocks, laccoliths, or

TABLE 1.-Chemical analyses, norms, and modes of igneous rocks from the Rattlesnake quadrangle

[Chemical analyses by P. L. D. Elmore, I. H. Barlow, S. D. Botts, and M. D. Mack, of the U.S. Geol. Survey, 1959 , by rapid rock analysis method]

\begin{tabular}{|c|c|c|c|c|c|}
\hline & 1 & 2 & 3 & 4 & 5 \\
\hline \multicolumn{6}{|c|}{ Chemical Analyses (weight percent) } \\
\hline 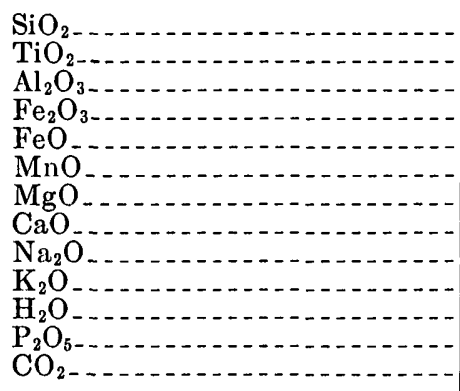 & $\begin{aligned} & 50 . 0 \\
& . 76 \\
& 11 . 3 \\
& 3 . 1 \\
& 5 . 7 \\
& . 17 \\
& 10 . 4 \\
& 8 . 0 \\
& 2 . 3 \\
& 3 . 2 \\
& 4 . 0 \\
& .77 \\
& . 30\end{aligned}$ & $\begin{aligned} & 57 . 0 \\
& .60 \\
& 14.5 \\
& 3.8 \\
& 3.0 \\
& .14 \\
& 4.6 \\
& 5.4 \\
& 4.1 \\
& 4.6 \\
& 1.2 \\
& .53 \\
& .05\end{aligned}$ & $\begin{array}{l}\text { 59. } 5 \\
.60 \\
\text { 15. } 5 \\
3.8 \\
2.9 \\
.18 \\
2.4 \\
5.3 \\
4.5 \\
3.9 \\
.64 \\
.44 \\
.13\end{array}$ & $\begin{array}{l}59.9 \\
\text { 16. } 0 \\
3.1 \\
2.8 \\
.17 \\
1.7 \\
3.8 \\
5.4 \\
3.9 \\
1.2 \\
.38 \\
.93\end{array}$ & $\begin{aligned} 66.9 \\
.24 \\
14.6 \\
1.7 \\
.82 \\
.06 \\
2.2 \\
1.9 \\
3.2 \\
6.1 \\
1.7 \\
.12 \\
.27\end{aligned}$ \\
\hline Total_ & 100 & 100 & 100 & 100 & 100 \\
\hline \multicolumn{6}{|c|}{ CIPW Norms (weight percent) } \\
\hline $\begin{array}{l}\text { Quartz } \\
\text { Orthoclase } \\
\text { Albite } \\
\text { Anorthite. } \\
\text { Corundum }\end{array}$ & $\begin{array}{l}18.9 \\
19.4 \\
11.1\end{array}$ & $\begin{array}{r}1.4 \\
27.2 \\
34.6 \\
7.5\end{array}$ & $\begin{array}{r}7.0 \\
22.8 \\
38.3 \\
10.6\end{array}$ & $\begin{array}{r}6.3 \\
22.8 \\
45.6 \\
8.1\end{array}$ & $\begin{array}{r}18.5 \\
36.1 \\
27.3 \\
7.0 \\
.1\end{array}$ \\
\hline $\begin{array}{l}\text { Diopside: } \\
\text { Wollastonite } \\
\text { Enstatite } \\
\text { Ferrosilite }\end{array}$ & $\begin{array}{l}9.2 \\
6.6 \\
\text { 1. } 7\end{array}$ & $\begin{array}{r}6.4 \\
5.0 \\
.7\end{array}$ & $\begin{array}{r}5.1 \\
3.7 \\
.9\end{array}$ & $\begin{array}{l}.9 \\
.6 \\
.3\end{array}$ & -1 \\
\hline $\begin{array}{l}\text { Hypersthene: } \\
\text { Enstatite } \\
\text { Ferrosilite }\end{array}$ & $\begin{array}{l}8.8 \\
2.2\end{array}$ & $\begin{array}{r}6.5 \\
.9\end{array}$ & $\begin{array}{r}2.3 \\
.5\end{array}$ & $\begin{array}{l}\text { 3. } 7 \\
\text { 1. } 9\end{array}$ & 5.5 \\
\hline $\begin{array}{l}\text { Olivine: } \\
\quad \text { Forsterite } \\
\text { Fayalite }\end{array}$ & $\begin{array}{l}7.4 \\
2.2\end{array}$ & & .0 & 1.0 & -- \\
\hline Magnetite & 4.4 & 5. 6 & 5. 6 & 4. 4 & 2: 1 \\
\hline Ilmenite & 1. 5 & 1. 2 & 1. 2 & .9 & .5 \\
\hline $\begin{array}{l}\text { Apatite } \\
\text { Hematite }\end{array}$ & 1. 7 & 1. 3 & 1.0 & 1.0 & .3 \\
\hline Total & 95. 1 & 98.3 & 99.0 & 96.5 & 97.7 \\
\hline
\end{tabular}


TABLE 1.-Chemical anatyses, norms, and modes of igneous rocks from the Rattlesnake quadrangle-Continued

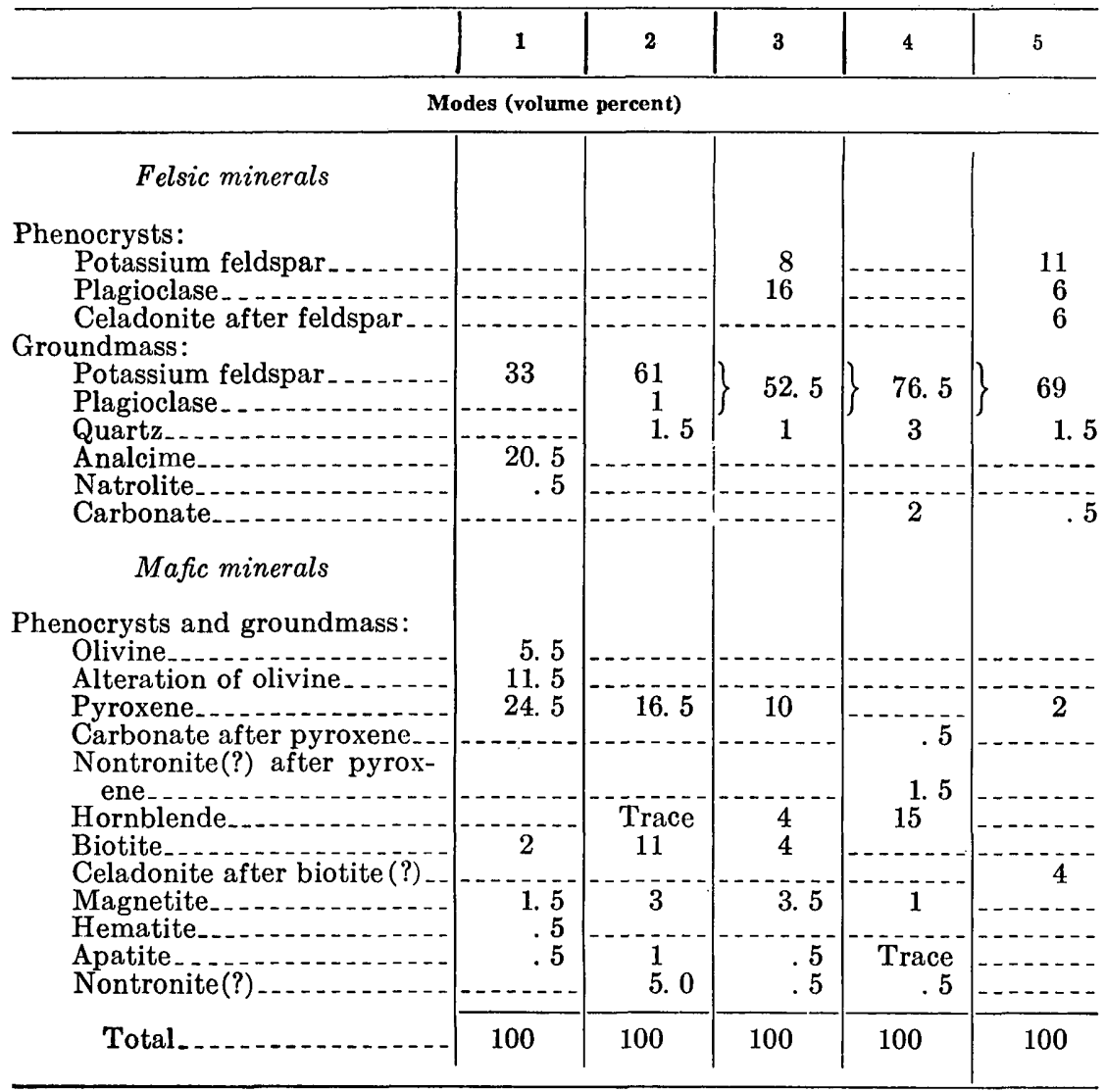

1. Mafic olivine-analcime phonolite; flow, 0.5 mile west of Rattlesnake Butte, in southeast cor. sec. 35, T. 28 N., R. $20 \mathrm{E}$. 'Specimen P58-104.

2. Mafic biotite-augite syenite; sill, 1.9 miles east-northeast of Black Butte, in southeast cor. sec. 32, T. 29 N., R. 20 E. Specimen P56-128D.

3. Porphyritic hornblende-feldspar latite; stock or bysmalith, near summit of Black Butte, in SW $1 / 4$ sec. 5, T. 28 N., R. 20 E. Specimen P58-122A.

4. Porphyrite hornblende-feldspar latite; stock or bysmalith, east side of Suction Butte, in $\mathrm{SW} 1 / 4$ sec. 12 T. 28 N., R. $20 \mathrm{E}$. Specimen P58-121.

5. Porphyritic quartz latite; flow, 1.5 miles southwest of Rattlesnake Butte; in NW $1 / 4$ sec. 2 , T. 27 N., R. 20 E. 'Specimen P58-120.

bysmaliths. A few are composite and contain two or more varieties of rocks. Locally, country rock is severely deformed and thermally metamorphosed. In the northern part of the quadrangle, shonkinite and syenite are subordinate, in area, to quartz latite in the proportion of about $1: 4$; but in the southern part of the quadrangle, shonkinite and syenite are the dominant intrusive rocks. Some linear and radial dike groups are composed of more than one variety of igneous rock.

Two general age relations for the intrusive rocks are as follows: (1) Most of the shonkinite intrusions are older than porphyritic latite, and (2) porphyritic syenite is a late intrusive variety. 


\section{SHONKINITW}

Augite and potassic feldspar (orthoclase, sanidine, microperthite) are the diagnostic minerals of the shonkinitic rocks. Biotite is present in varying amounts and in a general way is inversely proportional to the amount of olivine. Nepheline is diagnostic of hyperalkalic varieties. The shonkinites contain as much as 70 percent, by volume, of mafic minerals, and 40 percent is arbitrarily chosen as the limit between shonkinite and mafic syenite. In shonkinites having the lower percentage of mafic minerals (color index), the proportion of biotite to olivine is higher. Considerable variation in color index occurs in some shonkinite intrusions.

In coarse-grained shonkinites, feldspar characteristically is poikilitic. Many shonkinites are porphyritic, but all lack phenocrysts of feldspar. Phenocrysts of augite and biotite as much as 1 inch across are notable in the sill in secs. 17 and 20, T. 27 N., R. 20 E. Most shonkinites resist erosion poorly and form rounded summits or low-lying areas having a biotite-rich crumbly soil. Some shonkinites have abundant calcite, analcime, and other zeolites in the groundmass of the rock or in vugs. Other alteration products include chlorite, nontronite(?), and quartz. Magnetite, apatite, and sphene are the principal accessory minerals in the unaltered rocks.

The composite stock near Hansen Butte is about 1 square mile in area and contains the largest of the intrusive masses of shonkinite. The shonkinite is the oldest rock in the stock. In the southern part of the quadrangle, near Cromley Bench and Chimney Butte, shonkinite dikes define two fracture zones that trend for several miles in a northerly direction. Many dikes and sills of shonkinite show the syenitic "ribbon" fabric and "segregation patches" described by Pecora (1941). The ribbons indicate a sheeting that is approximately parallel to the border of the shonkinite intrusions.

At many localities in this quadrangle, shonkinite contains many inclusions of igneous and metamorphic rocks rafted up from the Precambrian basement. The fragments, as much as a foot in diameter, are like those in porphyritic latite. Their occurrence in shonkinites and mafic syenites in the eastern Bearpaw Mountains contrasts with their absence in shonkinitic rocks in the western Bearpaw Mountains. Where the inclusions occur profusely in this quadrangle, the shonkinite contains quartz but not nepheline. The quartz-rich inclusions, therefore, may have contaminated shonkinitic 
magma during ascent and caused a trend toward the silicic-alkalic family. Inclusions of carbonate rock derived from sedimentary formations of Paleozoic age are rare, and reaction rims are absent.

\section{SYENITE AND MAFIC SYENITE}

Potassic feldspar and augite are the two diagnostic minerals of the rocks mapped as syenite and mafic syenite. Biotite occurs in varying amounts, and olivine is rare or absent. Nepheline characterizes the few hyperalkalic varieties, and quartz characterizes contaminated varieties. Some varieties also contain small amounts of sodic plagioclase. As a group, syenite and mafic syenite intrusives contain mafic minerals in the range of $15-40$ percent, having an average about 30 percent. Thus they are gradational with the shonkinites. Syenitic ribbons or patches in shonkinite have a much lower color index, in the range of 1-10. In texture and alteration minerals, the syenites are like the shonkinites.

Intrusions mapped as syenite and mafic syenite make up about 10 percent of the intrusive rocks in the quadrangle. The largest exposed intrusion is a sill (roof mainly eroded) more than 150 feet thick located west of the Rattlesnake school. Part of a bysmalith of mafic syenite is exposed near Hansen Creek in NW1/4 sec. 27, T. 28 N., R. 20 E. Two separate units of mafic syenite in sec. 32 and sec. 33, T. 29 N., R. 20 E. are probably remnants of a single sill.

Most intrusions of syenite and mafic syenite are more resistant to erosion than are shonkinite rocks, and they form ridges, hills, ledges, and mesas. Their soils are like those on shonkinite but are lighter colored because of lower content of biotite and augite.

Chemical and petrographic data for a specimen of mafic syenite from the sill 2 miles east of Black Butte are given in table 1, column 2. The rock is massive and has a color index about 35. The fabric is trachytic and is dominated by homogeneous orthoclase laths in which are imbedded phenocrysts of augite and blades of biotite as much as $2 \mathrm{~mm}$ in length. Vugs make up about 5 percent of the rock and contain quartz, calcite, and nontronite(?). Accessory minerals include magnetite, apatite, and hornblende.

\section{PORPHYRITIC LATITE}

The map unit designated as porphyritic latite consists of felsic porphyritic rocks having fine-grained groundmasses that contain quartz, two feldspars (plagioclase and potassic feldspar), augite, hornblende, and biotite. Porphyritic latites normally are very resistant to erosion and form many high topographic features such as Black Butte, Myrtle Butte, Taylor Butte, Suction Butte, and Johnson Butte. The intrusive porphyritic latites make up about 12 square 
miles, or about 75 percent of the total area of intrusive rocks in this quadrangle. Most of these intrusions are in the northern part.

As a group, varieties of this rock are light gray to light brown, have a pronounced slabby sheeting reflecting a flow fabric, and contain phenocrysts of feldspar and dark minerals in a fine-grained matrix. The color index of the group ranges from 5 to 35 . Olivine is rare but occurs in some mafic varieties; where found, it is markedly resorbed. Some phenocrysts of plagioclase (oligoclase to labradorite) are mantled by potassic feldspar. Quartz is absent as phenocrysts but is common interstitially or in vugs.

In the field the porphyritic latite group cannot be reliably divided into quartz-free and quartz-bearing varieties because of the fine grain of the groundmass. However, the identity and proportions of the phenocrysts provide a useful mapping guide. For this purpose, augite is excluded from consideration because it occurs in all latites, and potassic feldspar and plagioclase are grouped together. Variations in assemblages can be recognized for biotite, hornblende, and feldspar. Most of the intrusions shown on the geologic map (pl. 1) are thus classified according to their phenocrysts. Hornblendefeldspar varieties make up the largest area as well as the largest number of intrusions. For 190 intrusions, representing more than 99 percent of the total area of intrusive latitic rocks, a tabulation based on the occurrence of phenocrysts is given below.

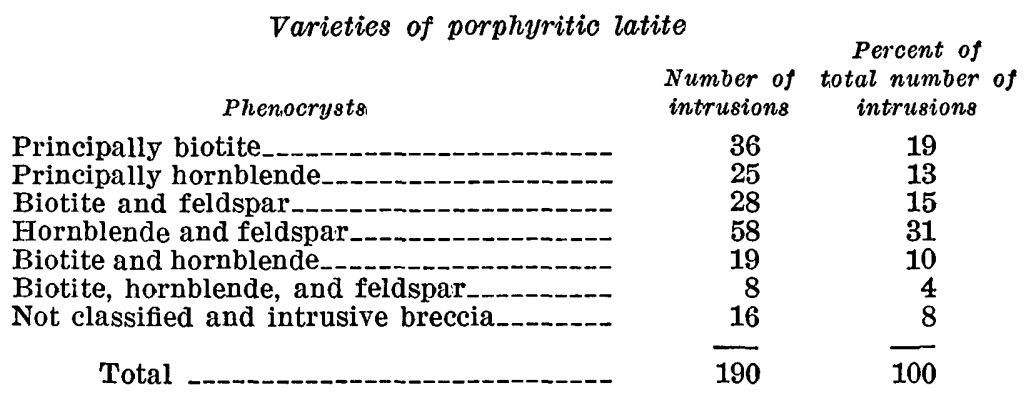

Each intrusion of porphyritic latite is essentially homogeneous. In a few composite intrusive bodies, all of which are discordant, contacts between different varieties are readily distinguished. As a group these rocks show none of the internal differentiation displayed by the shonkinites and mafic syenites, and age relations between varieties are only locally consistent. The genetic relation, therefore, of one variety of porphyritic latite to another is not clear.

All varieties of latite contain fragments of Precambrian crystalline rocks. At most these inclusions make up 2 percent of an intrusion by volume, although along some contacts the inclusions are more abundant. The inclusions comprise granite and granitic gneiss, 
pegmatitic granite, garnet-mica schist, amphibolite, anorthosite, gabbro, diorite, hornblendite, pyroxenite and peridotite, and biotiterich mafic rocks. Most fragments are subangular to subrounded and lack reaction rims. Inclusions of sedimentary rocks of Paleozoic age are rare.

Intrusive breccias of latitic composition occur in three areas: (1) on the north side of McDonald Basin, (2) northwest of Myrtle Butte, and (3) south of Rieve Butte. In general, these intrusions have steep contacts and irregular or pluglike shapes. The dike and the large area of intrusive breccia north of $\mathrm{McD}$ onald Basin are composed of angular to subrounded fragments, most of which are varieties of porphyritic latite having different color indices, and a few of which are shonkinite and sedimentary rocks. The fragments are enclosed in a matrix of fine-grained to very fine grained porphyritic latite and average about 2 inches across. The intrusive breccia south of Rieve Butte is similar but is slightly more altered, and that northwest of Myrtle Butte has a more mafic matrix and contains a greater proportion of inclusions of shonkinite and sedimentary rocks. The coherent nature and lack of extensive alteration of these breccias indicate that they may have been feeders for volcanic rocks.

Chemical and petrographic data for two latitic rocks from this quadrangle are given in table 1, column 3 (from Black Butte) and column 4 (Suction Butte). Both rocks are similar in chemical composition but are less silicic than latitic varieties recorded in published reports on adjoining quadrangles.

The hornblende-feldspar latite from Black Butte has a color index of 22.5 and contains zoned phenocrysts of potassic feldspar, plagioclase (andesine to labradorite) partly rimmed by or replaced by potassic feldspar, corroded hornblende rimmed by aggregates of biotite and magnetite, and pyroxene in an orthoclase-plagioclasequartz groundmass. The hornblende latite of Suction Butte has a color index of 18.5 and contains phenocrysts of corroded hornblende and relicts of euhedral pyroxene entirely replaced by carbonate and nontronite (?) in a subtrachytic, partly altered groundmass of plagioclase, orthoclase, and quartz.

\section{PORPHYRITIC SYENITE}

Porphyritic syenite in this quadrangle is restricted to two areas: dikes near Hansen Butte and discordant and concordant intrusions in an area trending northward from Suction Creek into the adjoining Cleveland quadrangle. Porphyritic syenite intrudes shonkinite, mafic syenite, and porphyritic latite; but, in the Hansen Butte complex, porphyritic syenite is intruded by a few dikes of porphyritic latite. 
Throughout the Bearpaw Mountains, felsic rocks assigned to the porphyritic potassic syenite group have a wide range of mineral and chemical composition. In the Rattlesnake quadrangle the porphyritic syenites related to that group lack feldspathoids and contain very small amounts of quartz. Zoned alkali feldspar phenocrysts 1-10 mm across dominate the texture and make up 20-60 percent of the rock. The feldspar is homogeneous or perthitic and commonly contains minute inclusions of plagioclase in its outermost zone. Phenocrysts of pyroxene having aegirinic borders, biotite, and hornblende also occur in small amounts. The groundmass is composed essentially of alkali feldspar (orthoclase), aegirine-augite, and interstitial quartz. Color index ranges from 10 to 20. Porphyritic syenite described in the Cleveland quadrangle by Weed and Pirsson (1896, p. 295) and Schmidt, Pecora, and Hearn (1964, table 1, col. 5) is similar in texture and mineralogy to the larger porphyritic syenite intrusions in the Rattlesnake quadrangle.

\section{METAMORPHISM}

Narrow zones of contact-metamorphic rocks, mainly spotted shale, hornfels and quartzite, occur near intrusive rocks in the Bearpaw Mountains structural arch. Calc-silicate rocks are rare because of the scarcity of calcareous rocks in the exposed sedimentary section. Silicification of the sedimentary rocks is the principal chemical effect of metamorphism.

Hornfels and quartzite derived from shale, siltstone, and sandstone are dark gray to white, closely jointed, and resistant to erosion. Bedding of the original sedimentary rocks has been preserved as banding. Hornfels and quartzite are well exposed near the Hansen Butte composite stock and around Rieve Butte.

Hardened and spotted shales, siltstones, and sandstones have been produced by metamorphism less intense than that which produced hornfels and quartzite. The spots range from microscopic to $2 \mathrm{~mm}$ in size and are generally darker than the matrix. They consist of concentrations of fine-grained opaque (carbonaceous?) material and a fine-grained brown micaceous mineral. Conspicuously spotted shale occurs in the basal part of the Fall River Sandstone Member in the Hansen Creek dome and north of Johnson Butte.

The calc-silicate rocks commonly contain carbonate and garnet, and less commonly, diopside, epidote, and vesuvianite. They occur only locally-for instance, in the limestones of the Kootenai Formation on the east side of the Hansen Butte composite stock and in the Rierdon Formation in the Taylor Butte dome and in the dome about 1 mile northeast of Black Butte. 
At many localities the extent of contact metamorphism is not directly related to the size of the adjacent intrusion. Several of the larger stocks have caused only slight hardening of the adjacent shales and no formation of the black spots, whereas some small intrusions, or even thin dikes, have produced an aureole of intense metamorphism to hornfels which is several times the width of the intrusion, as at Rieve Butte.

\section{EXTRUSIVE ROCKS}

The extrusive rocks occupy about 4.5 square miles in the Rattlesnake quadrangle and have an aggregate thickness of about 2,500 feet. They are divided into four mapping units: mafic flows, mafic pyroclastic rocks, felsic flows, and felsic pyroclastic rocks. These units are interlayered in the large areas of volcanic rocks. Locally the flow rock units include some pyroclastic beds, and the dominantly pyroclastic sequences include some thin flows. Mafic or felsic designation of pyroclastic units is determined by whichever of the two components (mafic or felsic rocks) makes up more than 50 percent of the deposit. The pyroclastic rocks include air-fall deposits (agglomerate, tuff-breccia, lapilli tuff, and tuff) and mudflows, conglomerate, sandstones, and siltstones derived from volcanic materials. Flow-rock units include flow breccias and massive and vesicular flows.

The volcanic rocks along the west edge of the quadrangle are contiguous with the main southern volcanic field of the Bearpaw Mountains, and they rest unconformably above, or are faulted against, sedimentary rocks of Cretaceous and early Tertiary (prevolcanic) age. In the central part of the quadrangle, isolated remnants of the formerly more extensive southern volcanic field have been preserved by recurrent downfaulting. Here, these volcanic rocks for the most part are unconformable over the Wasatch and Fort Union Formations and are faulted against Cretaceous formations along the borders of the blocks.

\section{MAFIC FLOW ROCKS}

Mafic flow rocks make up about 60 percent of the exposed extrusive rocks in the quadrangle. The flows consist of interbedded massive unaltered layers and rubbly altered layers which are grossly tabular in form but irregular in detail. The unaltered massive layers represent central parts of flows which have altered borders. Commonly a flow-breccia fabric of subangular to rounded blocks of vesicular altered flow rock in a matrix of similarly altered rock characterizes entire flows or tabular parts of flows. The flow breccias formed as the moving flows incorporated altered and chilled blocks from their own borders. Flows are approximately 5-30 feet thick. 
Some sequences of altered and unaltered layers can be attributed to a single eruption, since it is likely that the molten central part of a flow which had solidified chilled or altered borders repeatedly broke through to the surface and overrode the other parts of the flow. Many mafic flows were probably of wide lateral extent over terrain of low relief.

Unaltered parts of mafic flows weather dark gray to brown and are massive, well jointed, and resistant. Southwest of Rattlesnake Butte, unaltered parts of mafic flows crop out as typical discontinuous blocky ridges in a zone about half a mile wide. Altered parts of mafic flows are purple and red and form rounded rubbly discontinuous exposures. Altered parts are vesicular and rich in zeolitic amygdules, and they contain veins of zeolites and calcite which are locally crosscutting.

The mafic flow rocks are largely mafic phonolite and are chemically equivalent to nepheline shonkinite and shonkinite. The mafic phonolites are dark, fine grained, and porphyritic. Mafic phenocrysts are olivine, biotite, and pyroxene; analcime is the only felsic phenocryst, and it occurs in most but not all of the mafic phonolites. Both analcime and olivine are more abundant in mafic phonolites than in shonkinites. The main groundmass minerals are sanidine, analcime, and pyroxene. In altered rocks, analcime, natrolite, other zeolites, and calcite fill vesicles and impregnate the groundmass.

The chemical analysis, norm, and mode of a typical fresh maficphonolite flow west of Rattlesnake Butte are given in table 1. The rock consists of euhedral olivine (partially pseudomorphed by saponite or nontronite, chlorite, and hematite), euhedral pyroxene, small grains of biotite, and euhedral analcime set in coarse interlocking crystals of orthoclase but contains some areas of intergrown fine-grained orthoclase and analcime. As in other rocks of this region, analcime occurs in two habitats: as euhedral cloudy crystals (primary) forming phenocrysts or in the groundmass and as clear crystals in vugs and veinlets associated with natrolite, calcite, and other alteration minerals.

\section{MAFIC PYROCLASTIC ROCKS}

Mafic pyroclastic rocks are predominantly tuff-breccia but also include crystal and lithic tuffs, lapilli tuffs, agglomerates, and mudflow deposits as well as interlayered sandstone and conglomerate derived from mafic volcanic rocks. The deposits consists mainly of fragments of mafic phonolite, but all the mafic pyroclastic deposits contain some fragments of latite and quartz latite. Fragments are subangular to angular, attain a maximum diameter of about 4 feet in agglomeratic deposits, and show varying alteration. The deposits are 
generally brown to olive drab and poorly bedded, and they underlie grassy valleys or crop out as badlands. Mafic pyroclastic rocks are well exposed in the north half of sec. 2, T. 27 N., R. 20 E., and in the west half of sec. 11, T. 26 N., R. 19 E.

\section{FELSIC FLOW ROCKS}

Felsic flow rocks make up less than 10 percent of the total area of extrusive rocks in the quadrangle. They occur as flows and flow breccias of porphyritic latite and porphyritic quartz latite and are chemically equivalent to the intrusive porphyritic latites but are generally finer grained and more altered. Felsic flow rocks are reddish brown, greenish brown, and light brown or light gray, resistant, and closely jointed. The greenish color of the felsic flows and pyroclastic rocks is due to celadonitic alteration. The felsic flow rocks are invariably porphyritic, having zoned feldspar (sanidine and plagioclase), pyroxene, and biotite as phenocrysts and a fine-grained altered quartz-rich felsic goundmass. Inclusions of Precambrian rocks are common.

Most felsic flows have a limited lateral extent, probably because of their original high viscosity. The maximum thickness of groups of flows is about 300 feet. Some rocks mapped as felsic flow rocks may be in part intrusive into the volcanic pile, but their fine grain size and their alteration indicate shallow emplacement and volcanic affinity as compared with intrusives in the arch. Examples are the small units mapped as felsic flow rock in the east half of sec. 35, T. 28 N., R. 20 E.; these rocks are highly brecciated and have steep contacts.

A devitrified glassy felsic flow in secs. 2 and 3, T. 27 N., R. 20 E., consists of interlayered zoned of rubbly flow breccia and massive flow-banded rock having dark streaks. The chemical analysis, norm, and mode of a flow-banded zone are given in table 1, column 5. The rock of this flow-banded zone contains phenocrysts of potassic feldspar and plagioclase partially replaced by celadonite, euhedral pyroxene, and celadonite pseudomorphs after biotite(?). The phenocrysts are enclosed in a fine-grained felsic devitrified groundmass.

\section{FELSIC PYROCLASTIC ROCKS}

The felsic pyroclastic rocks, made up mainly (more than 50 percent) of fragments of varieties of felsic volcanic rocks, are predominantly tuff-breccia containing coarse blocks; but they also include some agglomerate, tuff, lapilli tuff, mudflow deposits, and waterlaid, sorted material. These rocks are of fairly limited lateral extent, and their maximum thickness is about 200 feet. Fragments of mafic volcanic rocks and Precambrian basement rocks are present in most of the felsic pyroclastic rocks. Component latite fragments are 
subangular to angular; commonly white, tan, greenish brown, or reddish brown; and as much as 4 feet in diameter. Their mineralogy is similar to that of felsic flows. The most extensive felsic pyroclastic deposit occurs in sec. 35, T. 28 N., R. 20 E.; thin deposits are well exposed in sec. 11, T. 26 N., R. 19 E., in the southwest corner of the quadrangle.

\section{STRUCTURE}

\section{REGIONAI SETTING}

The Bearpaw Mountains, one of the isolated mountain groups in the plains east of the main chain of the Rocky Mountains in Montana, can be divided into three structural provinces: the structural arch, the northern and southern volcanic fields and their collapsed borders, and the plains area. The mountainous area is made up of the arch and the two volcanic fields flanking it on the north and south.

The Bearpaw Mountains structural arch is an east-trending broadly anticlinal composite uplift which extends about 40 miles across the center of the mountains. It contains a great variety of intrusive igneous rocks in many structural forms. Sedimentary rocks exposed within the arch are mainly units of the Colorado Shale; but rocks as old as Jurassic are exposed in the central parts of many domes, and limestone of Mississippian age is exposed in two domes. In the western and central Bearpaw Mountains, the exposed arch is about 6 miles wide. In the eastern Bearpaw Mountains the exposed arch is a broad, composite, circular uplift 15-18 miles in diameter. The northern half of the Rattlesnake quadrangle embraces about two-thirds of this composite structure.

The volcanic fields consist of layered sequences of flows and pyroclastic rocks which dip predominantly toward the archsouthward in the northern field and northward in the southern field-but local variations in dip are common. Monoclinal dip within the fields and tilted and downfaulted blocks along the borders of the fields are the typical features. Within each field are intrusive bodies, some of which are probable sources of the volcanic rocks. At some places along the plainsward borders of the volcanic fields, volcanic rocks rest with an angular unconformity on faulted Cretaceous and Tertiary formations; at other places, volcanic rocks are in fault contact with the same formations. Block faulting, therefore, occurred prior to volcanism in some places and followed volcanism in others; most likely it was recurrent in character. Block faulting is believed to be the result of a collapse phenomenon. The Rattlesnake quadrangle contains both parts of the eastern border of the southern 
volcanic field and isolated remnants of this field preserved in downfaulted blocks.

The plains area for a maximum distance of about 30 miles south of the Bearpaw Mountains is characterized structurally by wide expanses of flat-lying or gently dipping Cretaceous rocks broken by elongate irregularly arcuate faults and folds, some of which are crudely circumferential and some of which are crudely radial to the Bearpaw Mountains. The faults were called shallow thrusts by Reeves (1924a, $\mathrm{b} ; 1925 ; 1929 ; 1946)$ and ascribed by him to deformation of the foreground of a huge major landslide-plainsward movement of the whole volcanic pile and some of the underlying sedimentary rocks. A few similar arcuate faults and folds are known in the plains area north of the Bearpaw Mountains, but whether their overall pattern and concentration are comparable with those south of the mountains is unknown because of the extensive cover of glcaial drift. Most of the southern half of the Rattlesnake quadrangle is in the structural province of the plains area.

The Rattlesnake quadrangle from north to south thus presents three structural provinces that are part of a regional picture: a broad complex dome-the Cleveland composite dome--that is the eastern part of the Bearpaw Mountains structural arch, a blockfaulted area that is immediately south of the dome and is related to the southern volcanic field, and a plains area that contains three well-defined lineaments that extend southward beyond the quadrangle boundary. Each province is described more fully in the following sections.

\section{BEARPAW MOUNTAINS STRUCTURAT ARCH}

\section{STRUCTURAL RELTEF AND PATTERN}

The eastern end of the Bearpaw Mountains structural arch has the shape of a circular composite "flat-topped" uplift having steep sides and an uneven roof surface due to the cluster of subsidiary domes. This circular uplift is herein named the Cleveland composite dome after the town of Cleveland, located just north of the quadrangle boundary.

The dominant pattern of structural elements (anticlinal and synclinal folds, dikes, and elongate outcrops of many intrusions) in the Cleveland composite dome is radial to the Hansen Butte composite stock. A subsidiary intersection of two sets of structural elements, one set of which is part of the major radial pattern, is located about half a mile west of Myrtle Butte.

Sedimentary rocks in the central part of the arch are mainly members of the Colorado Shale. The basal Cretaceous Kootenai 
Formation is the oldest exposed formation in seven domes, two of which are very small. In six other domes the Jurassic Rierdon Formation is the oldest sedimentary rock exposed; rocks older than the Rierdon, down to the Mississippian Mission Canyon Limestone, are exposed only in the Suction Creek dome.

The average structural relief of the arch in the area of abundant intrusions is about 3,500 feet; maximum structural relief inferred by projection of eroded roof rocks is about 7,000 feet. Domes such as the Taylor Butte dome and Hansen Creek dome near the outer edge of the arch have approximately the same amount of structural relief with respect to the plains as does the dome near Hansen Butte, in the center of the arch (sections $A-A^{\prime}$ and $B-B^{\prime}$, pl. 1).

\section{FAULTS}

Faults in the arch are less abundant and have less displacement than those south of the arch. Within the arch the average stratigraphic displacement is about 300 feet. Most faults are steep to vertical and have normal or dip-slip displacement. The maximum exposed displacement is about 700 feet across the two faults in the northwest side of the Suction Creek dome, but inferred displacements above some intrusions are at least 1,500 feet. Faults are generally sharp and rarely have brecciation. Some faults are composite, and the displacement is taken up on several subparallel sharp faults between which are relatively undeformed slices.

A descriptive term, "trapdoor fault block," is here applied to several structures. Generally, trapdoor fault blocks consist of uplifted sedimentary rocks which abut against discordant intrusive rocks or overlie concordant intrusive rocks. A trapdoor fault block has an unfaulted hinge zone of flexure and is bounded on two or more adjacent sides by steep faults or by a single curved fault (concave toward the hinge zone). The displacement is interpreted to be a result of upward drag along discordant intrusive contacts or uplift of a roof over concordant intrusions. The best example of a trapdoor fault block is the central part of the Taylor Butte dome (described in detail in a later section); other examples are the fault block of the dome 1.5 miles west of Myrtle Butte and the fault block of the dome east of Suction Butte.

\section{FOLDS}

Elongate domes and intervening basins show a well-defined radial pattern within the Cleveland composite dome.

Folds in formations above the Kootenai tend to increase in abundance and decrease in wavelength toward the center of the arch. The Kootenai and the Jurassic formations, although close to major 
intrusions, are rather competent and thus have not been as tightly folded as have formations that occur stratigraphically higher. The contrast between the character of the folds in the Eagle Sandstone of the Montana Group and the character of the folds in the Greenhorn Limestone and Mowry Shale Members of the Colorado Shale southwest of the Hansen Butte complex and in the Wilson Desert area is partly due to proximity to major intrusions, but it is also related to relative competency. The Eagle Sandstone is a thick competent formation whereas the Greenhorn and Mowry are thin competent members between much thicker, incompetent members.

\section{FFFECT OF INTRUSIONS}

Intrusive rocks have played a dominant role in the formation of the Bearpaw Mountains structural arch. Abundant evidence indicates that most of the uplift was due to forcible intrusion of igneous rock: nearly all domes have central cores of igneous rock; trapdoor fault blocks occur adjacent to or over intrusions; fault displacements increase toward intrusions; dip of wallrock steepens toward many intrusions. In the Cleveland composite dome the only example of subsidence adjacent to intrusions is on the south side of Myrtle Butte where a block of Eagle Sandstone has been downfaulted against the upper part of the Colorado Shale. Otherwise, those intrusions which have closely adjacent deformation seem to have exerted upward and outward force during their injection. Domes having igneous cores are described below in conjunction with the form and structure of intrusions.

The largest dome in the quadrangle, the Suction Creek dome, is complex, and the domal shape is not clearly related to any of the exposed intrusions. In another large dome (of which only the southern half is in this quadrangle) in secs. 28 and 29, T. 29 N., R. 20 E., the existence of an igneous core is questionable. A few smaller domes-for example in sec. 6, T. 28 N., R. 21 E., and in NW1/4 sec. 18, T. 28 N., R. 20 E.-have no exposed igneous core.

In the Suction Creek dome, formations older than the Colorado Shale are exposed over an area of about 2 square miles, and the Mission Canyon Limestone is the oldest formation cropping out. Even though several intrusions occur within the dome, none is clearly responsible for the doming. The porphyritic hornblende latite of Suction Butte has domed up its wallrocks along the southwest to northwest perimeter; but the sedimentary rocks in the main part of the dome on the northeast side dip toward the intrusion, and the faults bordering the dome die out as they approach the intrusion. Two other varieties of intrusive rock in the dome are porphyritic latite and shonkinite; porphyritic latite occurs in an elongate dikelike body 
which has injected the north fault zone, and shonkinite occurs as small dikes and sills in the dome and as thin dikes in the north boundary faults. Any of the three intrusive rock types may connect with a larger doming intrusion at depth.

In the dome in secs. 28 and 29, T. 29 N., R. 20 E., shonkinite exposed beneath the oldest beds which crop out in the structure (NW. cor. sec. 28) is probable the upper part of a sill, as a drill hole a third of a mile to the north (Pan American Petroleum Corp. Kuhr 1) in the Cleveland quadrangle penetrated a normal thickness of sedimentary rocks without major igneous units down to the Upper Cambrian. Whether the dome contains an igneous core below that level is unknown.

\section{FORM AND STRUCTURE OF INTRUSIONS}

Structural types of intrusive bodies in the Bearpaw Mountains structural arch include dikes, sills, stocks, laccoliths, and bysmaliths. Dikes dip $70^{\circ}$ or more, range in width from a few inches to 600 feet, and range in length from less than 10 feet to 3 miles; they are most numerous in the Hansen Butte area. Examples of large dikelike intrusions are south of Hansen Butte, half a mile southeast of Rieve Butte, northwest of Black Butte, and 1 mile southwest of Scotty Butte.

Sills range from 6 inches to about 400 feet in thickness and to as much as 1.5 miles in exposed lateral dimension. Examples are the mafic syenite sill east of Hansen Creek in secs. 26 and 27, T. 28 N., R. $20 \mathrm{E}$; t the porphyritic latite sill around McDougal Basin; the mafic syenite sill north of Myrtle Butte in sec. 14, T. 28 N., R. 19 E.; the mafic syenite sill east of Rieve Creek in secs. 32 and 33, T. 29 N., R. 20 E.; and the porphyritic latite sill northwest of Wilson Desert in secs. 23 and 24, T. 28 N., R. 20 E. Within the Colorado Shale the abundance of sills in the Greenhorn Limestone and Mowry Shale Members demonstrates that the injecting magmas preferred the competent members rather than the incompetent members.

Many of the large simple and composite masses of intrusive rock are stocks and plugs of rounded to irregular outline, and they range in area from about 1 square mile down to about one-third of an acre. Some of the larger stocks are the Hansen Butte composite stock, the stock of prophyritic latite north of McDonald Basin, and the stocks of porphyritic latite at Johnson Butte, Suction Butte, and Myrtle Butte. Examples of small plugs are the intrusions at Rieve Butte and the intrusion of porphyritic hornblende latite in the south half of sec. 9, T. 28 N., R. 20 E. Both concordant and discordant contacts occur on the perimeters of large stocklike intrusions-for example, the composite porphyritic latite body north of McDonald 
Basin. Stocks are composed of porphyritic syenite, shonkinite, and porphyritic latite, in order of increasing abundance.

The intrusions immediately south of Black Butte and south of Johnson Butte are composite stocklike bodies in which porphyritic latite occurs between the shonkinite core and the domed sedimentary wallrocks. In both, the porphyritic latite is intrusive into shonkinite and has been injected along the preexisting contact.

The stocks of porphyritic latite north of McDonald Basin and west of and including Myrtle Butte are composite in that they are composed of different varieties of porphyritic latite.

The Hansen Butte composite stock has complex intrusive relations of porphyritic latites, shonkinite, and porphyritic syenite. Shonkinite is the oldest phase of the stock; the main body of porphyritic latite is younger. Emplaced into the shonkinite-porphyritic latite complex and the surrounding sedimentary rocks are radial dikes which accentuate the Hansen Butte area as an intrusive center. A pluglike fine-grained porphyritic hornblende latite mass near the center of the complex cuts the main shonkinite and porphyritic latite bodies; it contains no dikes and probably was emplaced in the closing stages of igneous activity. This plug is probably not the source for the radial dikes because it is markedly different from them petrographically. Some of the folds and domes which are radial to the Hansen Butte area are cut by postdoming dikes of the radial set. In summary, all the radial structures of the arch cannot be due to a single event-that is, a catastrophic intrusion at the Hansen Butte complex-but some of them must be ascribed to longer-acting deep-seated forces operating throughout much of the intrusivetectonic history of this part of the structural arch.

For some domes, reconstruction of the deformed sedimentary rocks shows that dilation was sufficient to accommodate the central intrusion; for other domes, dilation alone was not enough, and upfaulted roofs are postulated, in the absence of any evidence of stoping, to explain the accommodation. The domes about threefourths of a mile southeast of Scotty Butte and northeast of Black Butte are wide in comparison to their igneous cores; thus the intrusions did not lift a faulted lid but were accommodated principally by dilation at or near this level of exposure. Two forms, pipelike (bottomless) or floored, or forms gradational between the two, are possible at depth.

Examples of intrusions which have not dilated their wallrocks enough to make room for the volume of intrusive rock are the intrusions of Black Butte and Johnson Butte and the composite intrusion of porphyritic latite north of McDonald Basin. These 
intrusions may have made room by raising faulted roofs, all or most of which have been removed by erosion. Formation of a pipelike mass would require fragmentation of the roof above the intrusion and inclusion of the broken sedimentary rocks in the intrusion or in surface flows and pyroclastic deposits to explain the volume problem; so, as inclusions of sedimentary rocks are rare in both the extrusive and intrusive rocks, it is unlikely that these intrusions are pipelike masses.

Several sill-like intrusions which have relatively small lateral extent, as compared to estimated thickness, may be laccoliths. Among them are the following: Porphyritic latites in Taylor Butte, in Scotty Butte, along Peoples Creek in secs. 25 and 36, T. 29 N., R. $19 \mathrm{E}$., half a mile northeast of Scotty Butte, about 1 mile east of Black Butte, and 1 mile northwest of Myrtle Butte; mafic syenite three-quarters of a mile north of Suction Butte; and shonkinite 11/2 miles west of Myrtle Butte. Where exposed, the upper and lower contacts of all these intrusions are conformable.

The term "bysmalith" was originally defined by Iddings (1898) for a modified laccolith, a floored intrusion which had lifted a roof entirely bounded by steep faults. The term has subsequently been used for laccoliths having partly faulted (trapdoor-faulted) roofs (Hunt, 1953) and for stocks encircled by steeply dipping faults (Goddard, 1950). In this quadrangle, two intrusions (one north of the intersection of Cow and Gap Creeks and one in the Hansen Creek dome, sections $C-C^{\prime}$ and $\left.A-A^{\prime}, \mathrm{pl}, 1\right)$ are interpreted to be bysmaliths (usage of Iddings), since they are probably floored and have their roofs surrounded by faults. Other intrusions which are thought to be laccoliths have merely arched their roofs and do not have major peripheral faults. Many concordant intrusions, having partially faulted roofs, are gradational in form between the two limiting types, laccolith and bysmalith. These gradational forms may be termed "bysmalithic" and are analogous to intrusions described by Hunt (1953).

\section{HANSEN CREEK DOME}

The best example of a bysmalith in the Rattlesnake quadrangle is in the Hansen Creek dome (section $A-A^{\prime}, \mathrm{pl}$. 1). A floor beneath the intrusion is assumed for reasons outlined below. The dome is rather flat topped, but dips are steep around the margin. The intrusion of mafic syenite exposed on the east side of the dome is probably responsible for the doming and is thought to extend beneath the entire dome because its upper contact is mainly comformable where exposed and because contact-metamorphic effects are identical at the same stratigraphic level over most of the dome. The preserved Kootenai 
Formation and Fall River Sandstone Member are virtually continuous across the dome but are offset by the border faults. If the intrusion is a "bottomless" stock having an upfaulted roof, a considerable volume of the Swift, Rierdon, Sawtooth, and older formations is missing in the space now occupied by the hypothetical stock and must have been either assimilated by the magma or stoped as blocks. However, there is no evidence for either assimilation or stoping, as the mafic syenite is not of unusual composition, nor does it contain any major inclusions of sedimentary rocks. Thus the volume occupied by the intrusion most probably has a floor made up of sedimentary rocks which are stratigraphically just below the lowest bed of the roof. The intrusion is quasi-conformable, not "bottomless," and is a laccolith having an uplifted roof ringed by faults-that is, a bysmalith, as the term was defined by Iddings.

\section{TAYLOR BUTTE DOME}

The Taylor Butte dome (section $A-A^{\prime}$, pl. 1), already mentioned as an example of trapdoor faulting, is another bysmalithic structure. The upper contacts of the core intrusion of hornblende latite are mostly conformable. When the dome is considered in cross section, problems similar to those discussed for the Hansen Creek dome are found: the roof is almost complete, and a volume problem arises if the intrusion is a "bottomless" stock. Also, the domal structure extends more than a mile south of the exposed part of the core intrusion, and a small pipe of closely similar porphyritic hornblende latite occurs on the south side of Taylor Butte. Thus, the porphyritic hornblende latite probably extends to the south at depth, and the floor of the intrusion is approximately the Sawtooth Formation. The intrusion is a bysmalith according to Hunt's (1953) use of the term-that is, the roof rocks form a dome across most of the intrusion but are broken above the steep side of the intrusion.

\section{TIMBER BUTTE INTRUSION}

Parts of the Timber Butte intrusion of porphyritic latite occur in the Maddux and Lloyd quadrangles, but most of the intrusion lies in the southwest corner of the Cleveland quadrangle and the northwest corner of the Rattlesnake quadrangle. The intrusion has a modified bysmalithic structure. It has lifted its roof about 600-800 feet, has pierced the roof, and has spread laterally above the roof. Most of the lower, bysmalithic part of the intrusion occurs in the Rattlesnake quadrangle. The preserved part of the roof is a conformable septum of gently north dipping beds of the Greenhorn Limestone Member and parts of the members above and below it. A small part of this septum lies along the north edge of the Rattlesnake quadrangle. 
Outside of this quadrangle the septum connects westward with the surrounding sedimentary rocks and ends northeastward within the intrusion. Flat to inward-dipping beds of the Greenhorn Limestone Member crop out beyond the perimeter of the southern part of the intrusion, which is approximately conformable above beds of the Carlile and Niobrara Shale Members. Similar mineralogy and texture indicate that the injection of the parts of the intrusion above and below the septum were contemporaneous or nearly so.

Other bysmalithic structures occur in the Rattlesnake quadrangle. The Suction Creek dome, faulted on two sides, was discussed in an earlier section. The dome 1.5 miles west of Myrtle Butte is similar in structure to the Taylor Butte dome but differs from the Taylor Butte dome in that most of the trace of a semicircular fault in its roof above the core intrusion of porphyritic biotite-feldspar latite has been obliterated by erosion. Southwest of the Cleveland composite dome, a shonkinite bysmalith immediately northeast of the junction of Gap and Cow Creeks lifted a roof of lower Judith River sandstone approximately 600 feet along a cylindrical fault (section $C-C^{\prime}, \mathrm{pl} .1$ ). About half of the roof is preserved.

\section{DEPTH OF DEFORMATION}

Three major conclusions are reached concerning the behavior of the crystalline basement beneath the Bearpaw Mountains structural arch: (1) the basement underlying the sedimentary cover of Paleozoic, Mesozoic, and Tertiary rocks was uplifted and faulted in the formation of the structural arch, although the deformed basement is nowhere exposed; (2) the major discordant intrusions now present in the sedimentary section pierced the basement as major intrusions, not as minor intrusions that subsequently flared out in the overlying sedimentary section; and (3) local lateral migration of magma occurred from many feeder dikes and plugs that pierced the basement and sedimentary section in the arch and caused a substantial amount of thickening of the cover above the crystalline basement. The principal effects of the concurrent deformation and magma movement were to create a first-order uplift, to set the stage for a major volcanic eruption, and to provide the circumstances for structura] collapse due to magma movement.

In the northern part of the quadrangle, the ratio of the width of the arch to the depth of an undisturbed top of the basement is about $10: 1$. If the basement is uplifted, as the authors believe, the ratio is about $18: 1$. The average structural relief within the 76 square miles that contain the arch in the Rattlesnake quadrangle is about 3,500 feet. This relief, converted to volume of an uplifted prism, is equivalent to about 50 cubic miles. The exposed intrusions, which 
cover about 16 square miles of the same 76 -square-mile area, would have to extend to a depth of about 3 miles to produce the 50 -cubic-mile volume of uplift, and thus would extend about $11 / 2$ miles below an undisturbed top of the basement below the arch. The volume of the uplift is, therefore, too great to be accounted for principally through displacement by intrusions within the sedimentary section above an undisturbed basement. Accordingly, the basement must have been displaced upward to account for part of the uplift.

Four holes have been drilled in the arch within and close to the Rattlesnake quadrangle. Two penetrated no igneous rock and two penetrated 40 percent igneous rock as conformable intrusions in the sedimentary section. The only drill hole in this quadrangle, in sec. 4, T. 28 N., R. 21 E. (Wood Calahan Oil Co. Govt. 1), plainsward from major intrusions, penetrated 820 feet of intrusive rock in a total depth of 2,270 feet.

Corroborative evidence for displacement of the basement during formation of the Bearpaw Mountains structural arch is found in the comparison between this arch and domes in the Little Rocky and Judith Mountains (Collier and Cathcart, 1922; Knechtel, 1944, 1959; Goddard, 1950). In the Little Rocky Mountains, Precambrian formations are exposed in the large domes formed around stocks of porphyritic syenite of Tertiary age. The major domes in the Judith Mountains are also formed by stocks that have broken through the Precambrian basement. The Cleveland composite dome is most likely similar to major domes in the Little Rocky and Judith Mountains.

\section{SOUTHERN VOLCANIC FIELD}

\section{SIGNIFICANCE OF FAULTED VOLCANIC ROCKS}

The southern volcanic field of the Bearpaw Mountains uplift at one time extended across the southern part of the Rattlesnake quadrangle, but only about $4 \frac{1}{2}$ square miles of the field remain. Four principal remnants of volcanic rocks are shown in the complexly faulted area in the central part of the quadrangle. In the southwest corner of the quadrangle, near Bullwhacker Coulee, the volcanic rocks are part of the main southern volcanic field. For the most part the volcanic units are in steep fault contact with adjacent formations of the Montana Group, and they overlie the Tertiary formations with an angular unconformity. Here and there a few small patches of volcanic rocks rest unconformably on Cretaceous rocks. Field relations in this quadrangle support the generalization drawn from earlier published quadrangle maps that most large areas of volcanic 
rock which are associated with Tertiary sedimentary formations are in fault contact with Cretaceous formations.

Around the border of the Bearpaw Mountains, Tertiary formations in large downdropped fault blocks are contiguous to relatively undisturbed Cretaceous rocks at the same topographic elevation. Recurrent faulting is characteristic of these faulted blocks, and patches of Tertiary rocks may have in a few places sloughed off the main blocks to rest as isolated units on undisturbed Cretaceous rocks. In many places along the border of the mountains, volcanic units in the basal part of the sequence unconformably overlie both Cretaceous and Tertiary formations that are in fault contact with each other and stratigraphically as much as 5,000 feet apart. Major block faulting, therefore, preceded volcanism at these places. Because the main volcanic sequence within large fault blocks persistently overlies Tertiary formations, synvolcanic and postvolcanic faulting must have recurred along many faults that were formed early in the tectonic history. The occurrence of isolated fault blocks of volcanic rocks in this quadrangle strongly suggests that similar patterns of faulting are concealed by the main volcanic field and that recurrent faulting played a dominant role in establishing the present structural character of the volcanic fields.

\section{FAULTS BORDERING THE VOLCANIC FIEID}

In the southwest corner of the quadrangle, a tilted sequence of volcanic rocks is cut off by a fault that extends into the Maddux quadrangle. The fault is actually a zone of slices of formations stratigraphically between the volcanic rocks and the Bearpaw Shale. Deformation is intense in the Bearpaw Shale near the fault zone, and the Fox Hills Sandstone has been downwarped against the fault. Within the layered volcanic sequence, drag along the fault is responsible for a synclinal fold whose axis is approximately parallel to the fault trace. Here the volcanic rocks everywhere lie on Tertiary formations.

West of Gap Creek, along the western margin of the quadrangle, volcanic rocks rest unconformably on faulted Tertiary and Cretaceous rocks. The long fault in secs. 23,26 , and 35, T. 28 N., $R$. $19 \mathrm{E}$., is the southeastward extension of a fault which approximately parallels the northeastern edge of the volcanic field. A part of the area of felsic volcanic rocks is intrusive, as evidenced by a volcanic plug, Birdtail Butte, just to the west of the quadrangle in sec. 34, T. 28 N., R. 19 E. 


\section{CENTRAL FAULTED AREA}

An eastward-trending complexly faulted area about 10 miles long in the central part of the quadrangle separates the Bearpaw Mountains structural arch from the plains area to the south. Because remnants of volcanic rocks are found in this complexly faulted area, the area is believed to represent the collapsed floor of a formerly more extensive volcanic field. The structural pattern, therefore, is one of differential collapse in which units as old as the Colorado Shale are in fault contact with volcanic rocks. On such faults, the stratigraphic separation is about 6,000 feet; however, this separation involves a vertical displacement that is not all postvolcanic in age. The topographic relief in the central faulted area is low, not exceeding 500 feet, and is mainly less than 200 feet.

An alternative hypothesis for the origin of this complexly faulted area is large-scale slide thrusting southward from the structural arch, modified by postslide collapse faulting and intrusion. The complex texture of the fault pattern suggests that such a hypothesis warrants close scrutiny. Detailed field relations, however, fail to support such an alternative hypothesis.

Tilted and gently folded formations characterize this faulted area. Broad folds, domal and basined structures, and gently tilted sequences are broken by faults, and flexures along some of these faults indicate sharp drag and shearing. Fault planes, where exposed, are smooth and slickensided and have little or no brecciation. Where fault displacement is largest, slices and wedges of different formations define a fault zone. Most faults are vertical to steeply dipping. Traces of several faults are curvilinear-the result of an irregularly curved fault surface rather than the topographic expression of the fault. Most of the recorded dip angles of fault planes are between $70^{\circ}$ and $90^{\circ}$; only a few are between $40^{\circ}$ and $70^{\circ}$; and none is below $40^{\circ}$. The full range of $40^{\circ}$ to $90^{\circ}$ has been observed along the same fault plane in sec. 3, T. 27 N., R. 20 E. Drag folds occur along some faults. Fault displacements tend to be absorbed in the incompetent Bearpaw and Claggett Formations. Vertical displacements along faults involving Cretaceous formations range from a few hundred to 1,500 feet; along faults involving Tertiary formations, displacement is as great as 6,000 feet.

The central faulted area is separated from the volcanic field exposed in the adjoining Maddux quadrangle to the west by a strip of west-dipping formations of the Montana Group. This strip forms the southwestern flank of a dome exposed along Gap Creek in sec. 36, T. 28 N., R. 19 E. The formations dip more steeply to the west 
as they approach the volcanic field west of the quadrangle boundary, and field relations suggest that the Bearpaw Shale in this strip abuts against the Wasatch Formation along a major fault largely concealed by volcanic rocks.

In an easterly direction the central faulted area abruptly ceases, and the southeastern flank of the arch passes gently into the plains structure. In the northern part of the faulted area, Claggett Shale is downfaulted against the Colorado Shale, breaking the continuity of the Eagle Sandstone along the southern flank of the arch. Farther south, Eagle Sandstone crops out in domal flexures broken by faults and surrounded by Claggett Shale. In the southern part of the faulted area, in secs. 9 and 16, T. 27 N., R. 20 E., a continuous sequence from Bearpaw Shale to Wasatch Formation dips $40^{\circ}$ to $75^{\circ}$ northeastward and, as a block, abuts against Claggett Shale along a fault. Nearby to the southwest, the Fort Union Formation abuts against Bearpaw Shale. The central faulted area thus is a randomly broken zone on the southern flank of the arch in which the young sedimentary rocks are preserved in fault contact with older rocks.

Some isolated collapse structures occur around the eastern and northeastern periphery of the Cleveland composite dome. These structures are down faulted blocks $1 / 4-2$ square miles in area in which beds as young as the Judith River Formation have been dropped along steeply dipping faults against formations as old as the Niobrara Shale Member. Most of the structures are in the Cleveland quadrangle (Schmidt, Pecora, and Hearn, 1964, pl. 1). The faults along the east edge of the Rattlesnake quadrangle, in sec. 33 , T. 29 N., R. 21 E. form part of one of the blocks and are about 6 miles from the east end of central faulted area of the Rattlesnake quadrangle.

A likely cause of collapse is the transfer of magma from deep in the basement to near-surface and surface environments. Complex fault patterns are not uncommon as a volcanic-tectonic collapse feature in many parts of the world, particularly where a large quantity of magma is involved.

\section{COLLAPSE BLOCKS NEAR RATTLESNAKE BUTTE}

Two areas of volcanic rocks underlain by Tertiary formations near Rattlesnake Butte exhibit some structural features, especially a curvilinear fault pattern, which suggest that they might have been involved in slide thrusts off the composite dome on the north. Many features associated with these blocks are found in other areas of volcanic rocks near the border of the mountains. Because the faults within and surrounding these volcanic areas near Rattlesnake Butte 
are steeply inclined, their present structural disposition was probably caused by extensive collapse faulting.

The volcanic layers in these collapse blocks are tilted predominantly to the north at angles as much as $90^{\circ}$. Near the southern borders of the collapse blocks the volcanic rocks overlie the Wasatch and Fort Union Formations with angular unconformity. Inliers of these Tertiary formations exposed beneath volcanic rocks within the collapse blocks indicate that the unconformity was extensive before faulting. Cretaceous formations surrounding the blocks have been downwarped and downfaulted toward the blocks in steplike fashion. Faults which have broken the volcanic rocks have repeated the sequence in some places. The total thickness of the layered volcanic rocks in the largest block is about 2,500 feet. Shonkinite and porphyritic latite intrude the volcanic rocks; some of the intrusions are younger than the faults. The maximum topographic relief on any of the blocks is about 500 feet.

A third area of volcanic rocks resting on Tertiary formations is a few miles west of Rattlesnake Butte in sec. 5, T. 27 N., R. 20 E. Here also the Tertiary rocks are in fault contact with surrounding Cretaceous rocks; but the fault plane is nowhere exposed, and its attitude cannot be measured. Topographic relief in this area of about one-fourth square mile is less than 80 feet. Field interpretation requires that this area be the surface expression of a downdropped prism.

Near Hansen Creek, in secs. 33 and 34, T. 28 N., R. 20 E., volcanic rocks in the basal part of the sequence unconformably overlie Cretaceous and Tertiary formations. This relation. is consistent with that found in other parts of the mountains. For the Cretaceous and Tertiary formations to be at nearly equal elevations prevolcanic faulting and erosion must have occurred. Because most, but not all, volcanic rocks in the Rattlesnake quadrangle are restricted to those areas within high-displacement prevolcanic faults, recurrent vertical movement must have occurred along these preexisting faults concurrent with the formation of new faults. Published geologic maps of the western and southwestern parts of the Bearpaw Mountains show normal faults of high displacement that require prevolcanic and postvolcanic movement. In the Rattlesnake quadrangle, evidence for any major plainsward sliding of the entire volcanic pile, as proposed by Reeves (1924b, 1946), is lacking. If such landsliding occurred, the evidence must be so concealed, destroyed or masked by later faulting and intrusions that the history of the landslide cannot be reconstructed. Current fieldwork southwest of the Rattle- 
snake quadrangle will enable more complete evaluation of Reeves' hypothesis.

\section{THE PLAINS AREA}

The flat structure of the plains area in the southern part of the Rattlesnake quadrangle is shown by the exposed Judith River and Bearpaw Formations and is broken by two principal kinds of structural features: linear fault-fold zones of the kind described by Reeves $(1924 a, b, 1925,1929)$ and shonkinite dikes that form a pattern radial to the composite dome occupying the northern part of the quadrangle. Whereas no evidence is seen for determining the relative ages of the two features, elsewhere in the region similar shonkinite dikes cut some of the fault-fold structures. Within this quadrangle, large shonkinite dikes parallel to two of the fault-fold lineaments are suggestive of some mutual structural relationship. Reeves $(1924 b, 1946)$ proposed that the fault-fold structures are controlled by thrust faults originating in the upper part of the Colorado Shale and caused by a major slide southward off the Bearpaw Mountains structural arch. A different proposal based on analysis of the structural patterns and relative age of the dikes would require that rock failure be due to shear forces translated into the sedimentary formations and that it be guided by major fractures that cut the Precambrian basement.

\section{FAULT-FOID IINEAMENTS}

Three fault-fold lineaments in this quadrangle are the Cow Creek lineament, the Als Creek lineament, and the Three Mile Ridge lineament. All three extend southward beyond the quadrangle boundary. The Cow Creek and Alls Creek lineaments form an acute-angle intersection in sec. 1, T. 26 N., R. 20 E., where the convergence of the two structures is marked by a block of Fort Union Formation in fault-contact with Bearpaw Shale. West of the Three Mile Ridge lineament, the exposed beds of Bearpaw Shale are 400600 feet structurally lower than the Bearpaw Shale exposed between the Three Mile Ridge and Als Creek lineaments. East of the Cow Creek lineament, near the quadrangle boundary, the Bearpaw is 100-200 feet structurally. higher than it is west of the lineament. Thus the plains area in the southwestern part of the quadrangle is structurally depressed with respect to the southeastern part, owing to the dislocations marked by these lineaments.

The Cow Creek lineament, exposed over a distance of about 10 miles in the Rattlesnake quadrangle, merges with the central faulted area of the quadrangle in the vicinity of sec. 9, T. 27 N., R. 20 E., and extends southeastward another 20 miles beyond the southern quadrangle boundary. In this quadrangle the Cow Creek lineament 
comprises a great number of discontinuous faults demarcating separate horsts, grabens, and folds. Most of the faults are vertical to steeply dipping, and displacements are normal and reverse. Horsts expose rocks as old as the upper part of the Colorado Shale, and grabens preserve rocks as young as Fort Union. Maximum displacement is, therefore, approximately 4,000 feet. As shown by Reeves (1924a, pl. 13), the lineament represents a major dislocation radial to the Bearpaw Mountains and, in the plains, transects several fault-fold lineaments that have southwesterly to southerly trends. East of the Cow Creek lineament and in part parallel to it is a prominent shonkinite dike that has been mapped for a total distance of about 8 miles. Because of the large displacements within the lineament and because of parallelism with the deep fracture represented by the dike, the lineament is most likely of deep origin.

The Als Creek lineament is exposed northeastward for about 3 miles in the Rattlesnake quadrangle and extends (Reeves, 1924a, pl. 13) for at least 35 miles southwestward beyond the quadrangle boundary; as mapped, it is one of the longest fault-fold features in the plains south of the Bearpaw Mountains. The numerous faults within this lineament are sinuous in trace, and most of them are low-angle to high-angle reverse faults. Within this quadrangle the lineament contains an anticlinal fold of Judith River beds and subordinate Claggett Shale that is structurally 600-800 feet higher than relatively undisturbed Bearpaw Shale on either side of the fault zone. The anticlinal fold was pierced by a drill hole (Mule Creek Oil Co. Cow Creek Govt. 1) about half a mile south of the quadrangle boundary, in sec. 23, T. 26 N., R. 20 E. At a depth of 1,585 feet in this drill hole, is a reverse fault along which the upper part of the Colorado Shale has been thrust over the lower part of the Claggett Shale-a stratigraphic displacement of about 1,000 feet. Below the reverse fault, the Eagle Sandstone was penetrated at a level several hundred feet below that of its normal position in the plains on either side of the lineament and about 1,200 feet below its upper occurrence in the anticlinal structure within the lineament. Several other faults were penetrated in the well between the surface and a depth of about 3,000 feet (lower part of the Colorado Shale), but none were found between 3,000 feet and the bottom depth of about 6,000 feet (beds of Ordovician age). The depth of Precambrian basement here is extrapolated to be about 4,150 feet below sea level.

The northeastward-trending Three Mile Ridge lineament is exposed for about 6 miles in this quadrangle and extends (Reeves, 1924a, pl. 13) at least 4 miles southwestward beyond the quadrangle boundary. The structure within the southern part of the 
fault zone in this quadrangle is anticlinal; the Claggett Shale is exposed in the core at a structural elevation about 1,000 feet higher than the elevation of unexposed Claggett on either side of the fault zone. West of the lineament a strip of Bearpaw Shale separates this lineament from the area of faulted Tertiary formations and volcanic rocks along the southeastern limit of the southern volcanic field. The lineament is bounded on the east and west by steeply dipping normal and reverse faults. The relative age of the fault system in the lineament and the fault to the west, between Bearpaw Shale and formations of Tertiary age, is indeterminate. Intensity of deformation decreases northeastward along the lineament. The limiting fault on the east, in secs. 29 and 32, T. 27 N., R. 20 E., is vertical to steeply dipping and does not extend to the Cow Creek lineament. Deformation of the Bearpaw Shale within the fault-fold lineament is probably more intense than is indicated on the map.

\section{RADIAL DIKE PATTERN}

In the southern part of the quadrangle, dikes are principally shonkinite. The dikes have a conspicuous radial pattern divergent southward. In the vicinity of the $\mathrm{T} U$ Bench, near the western margin of the quadrangle, dikes trend $\mathrm{N}$. $45^{\circ}-60^{\circ} \mathrm{E}$.; and, in the eastern part of the quadrangle, near Spring Coulee in sec. 4, T. 27 N., R. 21 E., dikes trend N. $45^{\circ}$ W. Chimney Rock, in sec. 9, T. 26 N., R. 20 E., marks a well-defined dike zone striking N. $20^{\circ} \mathrm{E}$; this dike zone parallels the Als Creek and Three Mile Ridge lineaments. The prominent dike striking N. $10^{\circ}-30^{\circ} \mathrm{W}$. east of the Rattlesnake School is probably the most persistent dike fracture zone of the radial pattern. The broad lateral extent of the dike pattern and the linear persistence of individual dike zones suggest that fractures of deep origin permitted shonkinite magma to rise several thousand feet to its present position in the sedimentary formations. Coincidence in trend of the principal dikes and the fault-fold lineaments supports the idea that both structural features are near-surface expressions of more deep-seated deformational patterns.

\section{SLIDE HYPOTHESIS OF RHEVES}

Reeves $(1924 b, 1946)$ proposed the hypothesis that late collapse of the Bearpaw Mountains region was preceded by large-scale plainsward sliding of the Bearpaw Mountains north and south of the structural arch and that the sliding took place on bentonitic zones in the upper part of the Colorado Shale. The fault-fold structures mapped south of the mountains in the quadrilateral area of several hundred 
square miles bounded by the Bearpaw, Little Rocky, Judith, and Highwood Mountains were interpreted by Reeves to be the "buckled foreground" produced by the low-angle thrust plate moving from the Bearpaw Mountains. Many contradictions arise in attempting to explain the structural features in the Bearpaw Mountains by the slide mechanism specifically proposed by Reeves. An alternative slide hypothesis would have large Tertiary masses sliding plainsward on the Bearpaw Shale, but the sliding would be unrelated to the faultfold lineaments in the plains area. The fact that prevolcanic, synvolcanic, and postvolcanic normal faulting and collapse structures are recognized makes any meaningful interpretation difficult without the aid of data from deep drilling.

Meager evidence from seismic surveys and drill holes in the plains area to date (1959) have indicated that, for some structural features in which Cretaceous formations are severely deformed and foreshortened, underlying Jurassic and Paleozoic formations are indeed arched. The fault-fold lineaments, therefore, may be directly related to deeper fracture-fold structures and are not necessarily a product of block slide on upper Colorado beds. In the southwestern part of the Bearpaw Mountains, substantial evidence exists for demonstrating that many faulted structures are older than rocks at the base of the volcanic sequence.

Hypotheses for the origin of the structural features in the area bordering the Bearpaw Mountains are currently being evaluated as fieldwork continues in the region. Structural analysis would require knowledge of the behavior of Paleozoic formations and of the basement surface.

\section{ECONOMIC GEOLOGY}

Economically significant ore deposits are not known in this quadrangle, although several prospect pits are shown on the map. Veins composed principally of pyrite, pyrrhotite, chalcopyrite, or hematite occur locally near the borders of large intrusions and their closely adjacent wallrocks. Sulfide minerals, found as disseminated small grains and in thin veins less than one-fourth of an inch wide, occur in several prospect pits in the Hansen Butte area. Residents of the area recall that minor amounts of gold were panned from Rieve Creek many years ago.

Oil and gas exploration within and close to this quadrangle has been unsuccessful. The Bowes field, north of the Bearpaw Mountains, is the nearest producing oil and gas field. The Eagle Sandstone contains gas, and the Sawtooth Formation contains producing oil zones. Drilling in the Sherard field (about 12 miles west of the 
southwest corner of this quadrangle) has yielded gas. The only drill hole in Rattlesnake quadrangle is Wood Calahan Oil Co. Govt. 1 in sec. 4, T. 28 N., R. 21 E. (see symbol on map). Drill holes close to the north edge of the Rattlesnake quadrangle are Pan American Petroleum Corp. Kuhr 1, in sec. 21, T. 29 N., R. 20 E., and Miller Bros., Inc., 1, in sec. 8, T. 29 N., R. 20 E.

Lignite and subbituminous coal were once mined for local use, as is shown by small surface and underground excavations, now largely caved. Coals and lignites of the upper part of the Judith River Formation are widespread in the southern half of the quadrangle; but the coal in the Fort Union Formation, although less abundant, is generally of higher rank and is thus a better fuel. Lignite and subbituminous coal occur at the base of the Hell Creek Formation and have been mined southwest of this quadrangle in sec. 22, T. 26 N., R. 19 E.

Leakage of stored water from small reservoirs is substantially decreased by the use of bentonite and bentonitic shale in earth dams or as a reservoir lining. Conspicuous beds of bentonite and bentonitic shale occur in the lower part of the Bearpaw Shale, Claggett Shale, and Colorado Shale (Niobrara Shale and Mowry Shale Members). Additional sources are thin bentonitic clay beds in the Judith River, Hell Creek, and Wasatch Formations.

Glaciofluvial deposits, pediment and terrace gravels, and alluvium are potential sources of gravel. Sand is available from the alluvium in valleys of major drainages. Igneous rock locally has been utilized for rip-rap and road metal; vesicular mafic flow rocks are particularly good for stabilizing road surfaces in shale areas.

Water is scarce in most of the area. Springs, some of which are shown on the map, provide water of varying quality; in general, water of the best quality issues from springs in the volcanic rocks, Eagle Sandstone, lower part of the Judith River Formation, and Fall River Sandstone Member. At depth in the east central part of the quadrangle, the Eagle Sandstone and basal sandstone beds of the Judith River Formation are likely sources of water, probably artesian, and elsewhere may also provide water to deep wells. Shallow wells are productive in alluvium and in some terrace deposits. In the $\mathrm{NW}^{1} / 4$ sec. $28, \mathrm{~T} .27 \mathrm{~N}$., R. 20 E., spring water is derived from the terrace gravel. Irrigation on the terraces between Cow Creek and Hedges Creek has resulted in seepage along the edges of the terrace-gravel deposits. The base of the alluvium in the sinuous melt-water channel in the northeast corner of the quadrangle is a particularly good aquifer, and in places it contains water at a depth of less than 10 feet. 


\section{REFERENCES CITED}

Alden, W. C., 1932, Physiography and glacial geology of eastern Montana and adjacent plains: U.S. Geol. Survey Prof. Paper 174, 133 p.

Bowen, C. F., 1914a, The Cleveland coal field, Blaine County, Montana : U.S. Geol. Survey Bull. 541, p. 338-355.

1914b, The Big Sandy coal field, Chouteau County, Montana: U.S. Geol. Survey Bull. 541, p. 356-378.

Brown, R. W., and Pecora, W. T., 1949, Paleocene and Eocene strata in the Bearpaw Mountains, Montana : Science, v. 109, p. 487-489.

Bryant, Bruce, Schmidt, R. G., and Pecora, W. T., 1960, Geology of the Maddux quadrangle, Bearpaw Mountains, Blaine County, Montana: U.S. Geol. Survey Bull. 1081-C, p. 91-116.

Cobban, W. A., 1945, Marine Jurassic formation of Sweetgrass arch, Montana : Am. Assoc. Petroleum Geologists Bull., v. 29, p. 1262-1303.

-1951, Colorado shale of central and northwestern Montana and equivalent rocks of the Black Hills: Am. Assoc. Petroleum Geologists Bull., v. 34, p. 2170-2198.

1958, Late Cretaceous fossil zones of the Powder River Basin, Wyoming and Montana: Wyoming Geol. Assoc. Guidebook, 13th Ann. Field Conf., Powder River Basin, p. 114-119.

1962, New Baculites from the Bearpaw shale and equivalent rocks of the western interior: Jour. Paleontology, v. 36, no. 1, p. 126-135.

Collier, A. J., and Thom, W. T., Jr., 1918, The Flaxville gravel and its relation to other terrace gravels of the northern Great Plains: U.S. Geol. Survey Prof. Paper 108-J, p. 179-184.

Collier, A. J., and Cathcart, S. H., 1922, Possibility of finding oil in laccolithic domes south of the Little Rocky Mountains, Montana: U.S. Geol. Survey Bull. 736-F, p. 171-178.

Goddard, E. N., 1950, Structure of the Judith Mountains, Montana [abs.] : Geol. Soc. America Bull., v. 61, p. 1465.

Hearn, B. C., Jr., 1959, Geology of the northern half of the Rattlesnake quadrangle, Bearpaw Mountains, Montana: U.S. Geol. Survey open-file report, $195 \mathrm{p}$.

Hunt, C. B., 1953, Geology and geography of the Henry Mountains region, Utah: U.S. Geol. Survey Prof. Paper 228, 234 p.

Hunt, R. E., 1956, Bowes field, Blaine County, Montana, in North Dakota Geological Society and Saskatchewan Geological Society, first international Williston basin symposium : Bismarck, N. Dak., Conrad Publishing Co., p. 186-191.

Iddings, J. P., 1898, Bysmaliths: Jour. Geology, v. 6, p. 704-710.

Imlay, R. W., 1952, Summary of Jurassic history in the western interior of the United States, in Sonnenberg, F. P., ed. Billings Geol. Soc. Guidebook, 3d Ann. Field Conf., Sept. 1952 : p. 79-85.

Imlay, R. W., Gardner, L. S., Rodger, C. P., and Hadley, H. D., 1948, Marine Jurassic formations in Montana: U.S. Geol. Survey Oil and Gas Inv. Prelim. Chart 32.

Kerr, J. H., Pecora, W. T., Stewart, D. B., and Dixon, H. R., 1957, Preliminary geologic map of the Shambo quadrangle, Bearpaw Mountains, Montana : U.S. Geol. Survey Misc. Geol. Inv. Map I-236.

Knechtel, M. M., 1944, Plains adjacent to Little Rocky Mountains, Montana : U.S. Geol. Survey Oil and Gas Inv. Prelim. Map 4. 
Knechtel, M. M., 1953, Pediments of the Little Rocky Mountains, north-central Montana [abs.] : Geol. Soc. America Bull., v. 64, p. 1445.

1959, Stratigraphy of the Little Rocky Mountains and encircling foothills, Montana : U.S. Geol. Survey Bull. 1072-N, p. 723-752.

Knechtel, M. M., and Patterson, S. H., 1956, Bentonite deposits in marine Cretaceous formations, Hardin district, Montana and Wyoming: U.S. Geol. Survey Bull. 1023, p. 1-114.

Lindvall, R. M., 1953, Geology of the Eagleton quadrangle, Montana : U.S. Geol. Survey Geol. Quad. Map GQ-29.

1956a, Geology of the Big Sandy quadrangle, Montana: U.S. Geol. Survey Misc. Geol. Inv. Map I-130.

1956b, Geology of the Kenilworth quadrangle, Montana: U.S. Geol. Survey Misc. Geol. Inv. Map I-129.

Nordquist, J. W., 1955, Pre-Rierdon Jurassic stratigraphy in northern Montana and Williston Basin: Billings Geol. Soc. Guidebook, 6th Ann. Field Conf., p. 96-106.

Pecora, W. T., 1941, Structure and petrology of the Boxelder laccolith, Bearpaw Mountains, Montana: Geol. Soc. America Bull., v. 52, p. 817-853.

Pecora, W. T., Hearn, B. C., Jr., and Milton, Charles, 1962, Origin of spherulitic phosphate nodules in basal Colorado Shale, Bearpaw Mountains, Montana: Art. 12 in U.S. Geol. Survey Prof. Paper 450-B, p. B30-B35.

Pecora, W. T., Witkind, I. J., and Stewart, D. B., 1957, Preliminary geologic map of the Laredo quadrangle, Bearpaw Mountains, Montana: U.S. Geol. Survey Misc Geol. Inv. Map I-234.

Pecora, W. T., and others, 1957, Preliminary geologic map of the Warrick quadrangle, Bearpaw Mountains, Montana: U.S. Geol. Survey Misc. Geol. Inv. Map I-237.

Pepperberg, L. J., 1909, Notes on the mineral deposits of the Bearpaw Mountains, Montana : U.S. Geol. Survey Bull. 430, p. 135-136.

1912, The southern extension of the Milk River coal field, Chouteau County, Montana : U.S. Geol. Survey Bull. 471, p. 359-383.

Pierce, W. G., and Hunt, C. B., 1937, Geology and mineral resources of north-central Chouteau, western Hill, and eastern Liberty Counties, Montana : U.S. Geol. Survey Bull. 847-F, p. 225-264.

Reeside, John B., Jr., and Cobban, William A., 1960, Studies of the Mowry Shale (Cretaceous) and contemporary formations in the United States and Canada: U.S. Geol. Survey Prof. Paper 355, 126 p.

Reeves, Frank, 1924a, Geology and possible oil and gas resources of the faulted area south of the Bearpaw Mountains, Montana: U.S. Geol. Survey Bull. 751-C, p. 71-114.

1924b, Structure of the Bearpaw Mountains, Montana: Am. Jour. Sci., 5th ser., v. 8, p. 296-311.

1925, Shallow folding and faulting around the Bearpaw Mountains: Am. Jour. Sci., 5th ser., v. 10, p. 187-200.

1929, Thrust faulting and oil possibilities in the plains adjacent to the Highwood Mountains, Montana : U.S. Geol. Survey Bull. 806-E, p. 155-195.

1946, Origin and mechanics of thrust faults adjacent to the Bearpaw Mountains, Montana: Geol. Soc. America Bull., v. 57, p. 1033-1048.

Rubey, W. W., 1930, Lithologic studies of fine-grained Upper Cretaceous sedimentary rocks of the Black Hills Region: U.S. Geol. Survey Prof. Paver 165-A, p. 1-54. 
Schmidt, R. G., Pecora, W. T., Bryant, Bruce, and Ernst, W. G., 1961, Geology of the Lloyd quadrangle, Bearpaw Mountains, Blaine County, Montana : U.S. Geol. Survey Bull. 1081-E, p. 159-188.

Schmidt, R. G., Pecora, W. T., and Hearn, B. C., Jr., 1964, Geology of the Cleveland quadrangle, Bearpaw Mountains, Blaine County, Montana : U.S. Geol. Survey Bull. 1141-P, p. P1-P26.

Stebinger, Eugene, 1914, The Montana Group of northwestern Montana : U.S. Geol. Survey Prof. Paper 90, p. 61-68.

1916, Possibilities of oil and gas in north-central Montana: U.S. Geol. Survey Bull. 641-C, p. 49-91.

Stewart, D. B., Pecora, W. T., Engstrom, D. B., and Dixon, H. R., 1957, Preliminary geologic map of the Centennial Mountain quadrangle, Bearpaw Mountains, Montana : U.S. Geol. Survey Misc. Geol. Inv. Map I-235.

Weed, W. H., and Pirsson, L. V., 1896, Igneous rocks of the Bearpaw Mountains, Montana : Am. Jour. Sci., 4th ser., v. 1, p. 283-301, 351-362; v. 2, p. 136-148, 188-199. 


\section{INDEX}

[Major references are In italic]

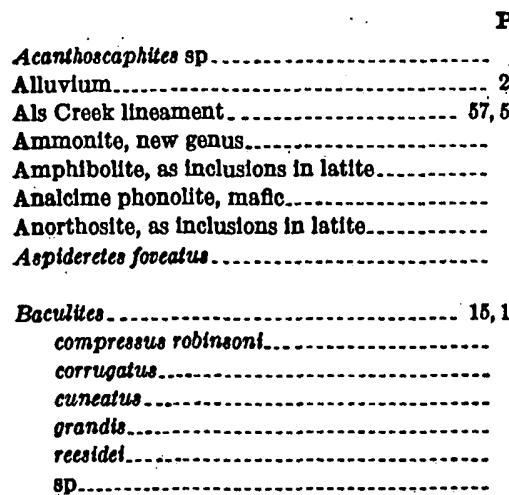

Bearpaw Mountalns structural arch...........

$12,39,43,44,46,47,51,62,54,67$

Bearpaw Shale........................... 4, 11 $16,18,19,31,63,84,55,57,58,59,60,61$ upper part, section of.

\section{Belemnttes}

Belle Fourche Shale Member, Colorado Bhale. 12, 14

Belt Berles.

Benches, Alden.............................. 28, 29, 30

Bentonite. ................................... 17, 191

Block feulting................................ 8,43

Bowes Member, Plper Formation............ 8

Bysmalithic structures................... 49, 80,51

Bysmaliths........................ 4, 34, 38, 47, 49, 50 shonkinite

$12,18,51$

Carllle Shale Member, Colorado Shale

Centennial Mountain quadrangle.

2,32

Cercldiphy hum areticum . ...................

Champsosaures sp.......................... 18

Claggett Formation............................ B4

Claggett Shale. . ............. 11, 16, $17,85,68,89,61$

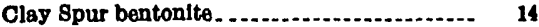

Cleveland composite dome....... 44,45,46, 51, 52, 55

Cleveland quadrangle.......... 30, 32, 38, 39, 47, 50, 56

Cosl..................................... 61

Collapse blocks................................ 66

Colorado Shale....... 11, 12, 13, 43, 44, 54, 65, 57, 88, 59

Continental toe sheet........................ 6

Cow Creek lineament . ................... 87, 88, 69

Cyprian Bandstone Member, Thermopolis Bhale.

Dikes. $4,33,35,38,47,51,58$ porphyritle latite.......................... 38,16 radial.................................... 67 shonkinite........................ $47,57,59$ Diorite, as inclusions in latite.
Eagle Sandstone...... B11, 16, 16, 17, 46, 55, 68, 60, 61

Economic geology............................... 60

Ellis Group $\ldots$

Extrusive rocks ................................ 40

Fall River Bandstone Member, Colorado. Shale.......................... 18, 50,61

Fault-fold lineaments . ..................... 60

Faulting...................... 40, 43, 44, 48, 81, 63, 64

Faults....................... $46,46,49,60,51,65,88$

Felstc fiow rocks . . . . .

Felsic pyroclastic rocks....................... 48

Ficus ceratops................................ 21, 23

Firemoon Limestone Member, Piper Formatlon. 8

First Cat Creek sand....... 18

Folds _ . . . . .

Fort Union Formation . - 22, 24, 27, 40, 56, 86, 57, 68, 61 sectlon of........................ 26

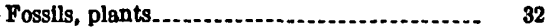

Fox Hills Sandstono................ 11, 20, 24, 27, 63 sectlon of ............................. 21

Gabbro, as inclusions in latite.............. 88

Geologic history..............................

Gervillia montanaensis _....................... 8

Glaclofiuvial deposits . ....................... 28, 50

Gnelss, granitic, as Inclusions in latite...... 37

Grabens............. 58

Granite, as inclusions in latite............

pegmatitic, as Inclusions in latite........- 88

Groanhorn Llmestone Member, Colorado Ghale............... 12, 14, 18, 46, 47, 50, 51

Gryphaca..................................... 10 nebrascensib.................................. 10

planoconoesd................................ 8

Hansen Butte composite stock....... 35, 39, 44, 47, 48

Hansen Creek dome.................. 14, 39, 48, 49,80 maflc syenite In ........................ 49

Hell Creek Formation.............. 11, 21, 24, 27, 61 section of.............................. 22

Hornblendite, as Inclusions In latite ......... 88

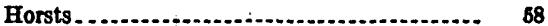

Igneous rocks.

Imlay, R. W., quoted.........

Inoceramus................... 16, 16

Inoceramus bellowensis

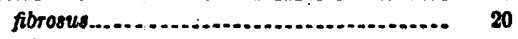

labiatus............. 16

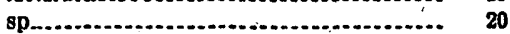

Intrusive breccls, latitlo..................... 88

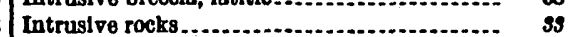


Kootenai Formation. $10,11,39,45,49$

Laccoliths $4,33,47,49,50$

Lamna sp.

Laredo quadrangle .

Latite, porphyritic porphyritio in blocks and

Lepidosteus sp.

Leurospondylus sp.

Linear fault-fold zones.

Lloyd quadrangle..

Lodgepole Limestono

Maddux quadrangle.

Madison Group.

Mafic flow rocks

Maflc pyroclastic rocks

Mapping units, Igneous.

Metamorphism

Metasequoia occidentalis

Mission Canyon Limestone

Montana Group.

Morrison Formation

Mowry Shale Member, Colorado Shale...... 12, $14,46,47,61$

Myrtle Butte rockslide......................... 27, 28

Nepheline shonkinite........................ 32,41

Newcastle Sandstono Member, Colorado

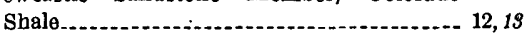

Niobrara Shale Member, Colorado Shale...... 12, $16,51,55,61$

OiJ and gas exploration

Ore deposits

Palaeoscincus costatus

Pediment gravels.............................. 24, 27, 28

Peridotite, as inclusions in latite.............. 38

Phonolite, mafic............................... 41

Pipe, porphyritic latite...................... $\quad 50$

Pipcr Formation............................... 78

Placenticeras meeki.......................... 18,20

Platanus haydeni.............................. 24

Plugs .............................. 4, 33, 38, 47, 51, 53 Precambrian basement...... 5, 32, 35, 37, 42, 52, 57, 58 Pyroxenite, as inclusions in latite............. 38

Quartz latite porphyritic

Radial dike pattern $\mathrm{B} 28, \$ 1$

Rhaeboceras whiteavesi........................ $\quad 20$

Rierdon Formation................. 7, 10,31, 39,45, 50 Saw tooth Formation....................... 7, 50, 6 section of.

Scaphites.......................................... 15, 1

Schist, as inclusions in latite.................. 3

Second Cat Creek sand ......................... 1

Shambo quadrangle........................... 2, 3

Shonkinite.................... $33,35,36,38,46,56,5$

Sills. ............................ $4,31,33,35,36,47,4$

porphyritic latite................... 4

shonkinite............................... 4

Skull Creek Shale Member, Colorado Shale _ 12,19

Slide hypothesis, Reeves.................. $\quad b 9$

Springs ................................................ 61

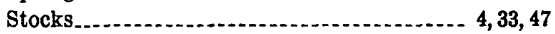

porphyritic latite........................ 47, 48

porphyritic syenite.......................... 48

shonkinite............................. 48

Suction Creek dome............ 6,8,10,11,45,46,51

porphyritic latite in .................... 46

section in

shonkinite in............................... 46

Surficial deposits . .......................... $\quad \boldsymbol{2 7}$

Swift Formation. ..................... 7, 10,31,50

Syenite_...

blocks of . .

mafic............... 35,38

porphyritic............................ 33, 34, 38

Syenite and mafic syenite ................... 33,36

Tampico Shale Member, Piper Formation... 8

Taylor Butte dome.............. 10, 11, 39, 45, 50, 51

Telegraph Creek Member, Colorado Shale... 12,

Third Cat Creek sand..................... 11

Three Mile Ridge lineament. . ........... 57,58, 59

Timber Butte intrusion .................. 50

Trapdoor fault blocks...................... 45, 46

Twin Creek Limestone...................... 8

Unio $\ldots \ldots$

Viburnum antiquum ........................... 24

Virgelle Sandstone . ....................... 16

Warrick quadrangle

Wasatch Formation............ 4, 24, 26, 40, 55, 56, 61 section of

Water, scarcity of .

59 Winters Creek, sections along ....... 20, 21, 22, 25, 27 
The U.S. Geological Survey Library has cataloged this publication as follows:

\section{Hearn, Bernard Carter, 1933-}

Geology of the Rattlesnake quadrangle, Bearpaw Mountains, Blaine County, Montana, by B. C. Hearn, Jr., W. T. Pecora, and W C Swadley. Washington, U.S. Govt. Print. Off., 1964.

iv, 66 p. maps (1 fold. col. in pocket) table. $24 \mathrm{~cm}$. (U.S. Geological Survey. Bulletin 1181-B).

Contributions to general geology.

Bibliography : p. 62-64.

(Continued on next card)

Hearn, Bernard Carter, 1933-

Geology of the Rattlesnake quadrangle, Bearpaw Mountains, Blaine County, Montana. 1964. (Card 2)

1. Geology-Montana-Blaine Co. 2. Bearpaw Mountains, Montana. I. Pecora, William Thomas, 1913- joint author. II. Swadley, W C, 1930- joint author. III. Title: Rattlesnake quadrangle, Bearpaw Mountains, Blaine County, Montana. (Series). 